Portland State University

PDXScholar

\title{
Hegemony in two mainstream Oregon newspapers : the war on poverty era vs. the post-Reagan era
}

Marcia R. Hood-Brown

Portland State University

Follow this and additional works at: https://pdxscholar.library.pdx.edu/open_access_etds

Part of the Sociology Commons

Let us know how access to this document benefits you.

\section{Recommended Citation}

Hood-Brown, Marcia R., "Hegemony in two mainstream Oregon newspapers : the war on poverty era vs. the post-Reagan era" (1992). Dissertations and Theses. Paper 4323.

https://doi.org/10.15760/etd.6207

This Thesis is brought to you for free and open access. It has been accepted for inclusion in Dissertations and Theses by an authorized administrator of PDXScholar. Please contact us if we can make this document more accessible: pdxscholar@pdx.edu. 
AN ABSTRACT OF THE THESIS OF Marcia R. Hood-Brown for the Master of Science ir Sociology presented May 8, 1992.

Title: Hegemony in Two Mainstream Oregon Newspapers:

The War on Poverty Era vs. the Post-Reagan Era.

APPROVED BY THE MEMBERS OF THE THESIS COMMITTEE:

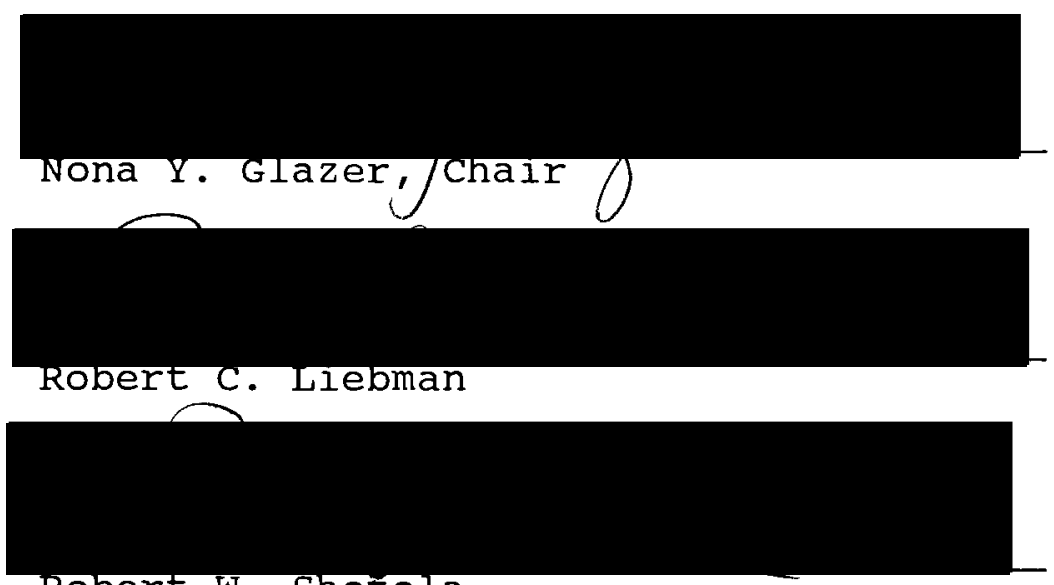

Robert W. Shotola

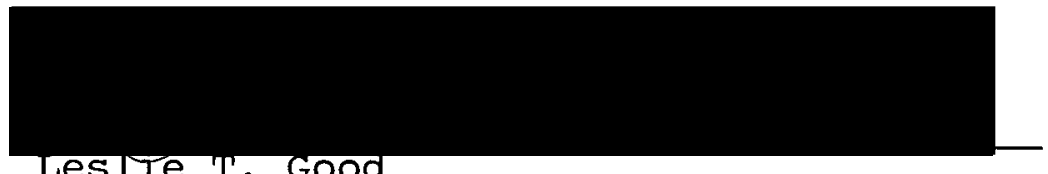

In my research I use qualitative content analysis to determine if and how the hegemony of the capitalist class in the United States influences the content of news texts on poverty. I analyze messages from two contrasting historical eras, the War on Poverty era and the post-Reagan era.

I began my research by identifying a dominant "conceptual frame", which is likely to be employed by elected officials in 
conceptualizing poverty, for each historical era. These frames are based on the federal policies promoted and implemented in each time period. The dominant frame for the War on Poverty stressed a "cultural deprivation" perspective on poverty, whereas the Reagan-era frame stressed a "situational factors" perspective. Both frames included an "individual responsibility" perspective on poverty. I then selected the calendar years from which I would draw my sample: 1969, a year of marked increases in human services funding in the state of Oregon; and 1990, the year in which Measure 7 passed, mandating dramatic cuts in social services.

When analyzing the content of the stories in my sample, I determined if the story as a whole was consistent with the dominant frame from that time period, or if the story presented a challenge to the dominant frame. A challenge to the frame presents a cause of or solution for poverty which is consistent with the "structural causes" perspective, a perspective which treats poverty as endemic to and caused by capitalism. Stories consistent with the frame may either actively support or merely accept the frame, and challenges to the frame may or may not be co-opted. I suspected that most stories in the sample would be consistent with the frame, and that any challenges to it presented would be co-opted. I suspected that a challenge to the dominant frame without co-optation would prove too strong a challenge to dominant class hegemony and would not be permitted by the 
capitalist cultural apparatus.

I also anticipated that the stories from 1969 would stress government-sponsored antipoverty programs and would emphasize racial minorities when discussing poverty. I expected that stories from 1990 would emphasize non-profit and charitable antipoverty programs, and would often discuss homelessness, substance abuse and mental illness along with poverty. Such differences in presentation illustrate how the content of hegemony changes to incorporate new information and possible challenging definitions of reality. I expected to find language which exemplifies the cultural deprivation perspective in the 1969 stories, and to find language exemplifying the situational factors perspective in 1990. I anticipated that language exemplifying the individual responsibility perspective would appear in stories from both years. Finally, I suspected that major stories spanning several daily editions would present many conflicting viewpoints and appear to be telling both sides of the story, but that challenging viewpoints would still always be coopted.

My analysis revealed that most of my initial expectations were correct, with one exception. Some stories did present challenges to the dominant frames without active co-optation through journalistic practices. I conclude, however, that even these non-co-opted challenges are still consistent with hegemony. Although the stories specify causes of and 
solutions for poverty which may be consistent with the structural causes perspective, they do not necessarily identify poverty as endemic to capitalism. Because the structural causes perspective is not part of capitalist hegemonic culture, the reader may not be sensitized to this perspective. A reader who lacks a structural interpretive scheme will interpret messages which are consistent with the structural causes perspective as being consistent with the dominant frame. I conclude that unless a news story presents the structural perspective in its entirety, outlining the central assumptions of structural theory, any challenge presented to the dominant frame is co-opted by omission. 
HEGEMONY IN TWO MAINSTREAM OREGON NEWSPAPERS:

THE WAR ON POVERTY ERA VS. THE POST-REAGAN ERA

by

MARCIA R. HOOD-BROWN

A thesis submitted in partial fulfillment of the requirements for the degree of

\author{
MASTER OF SCIENCE \\ in \\ SOCIOLOGY
}

Portland State University

1992 
TO THE OFFICE OF GRADUATE STUDIES:

The members of the committee approve the thesis of Marcia R. Hood-Brown presented May 8, 1992 .

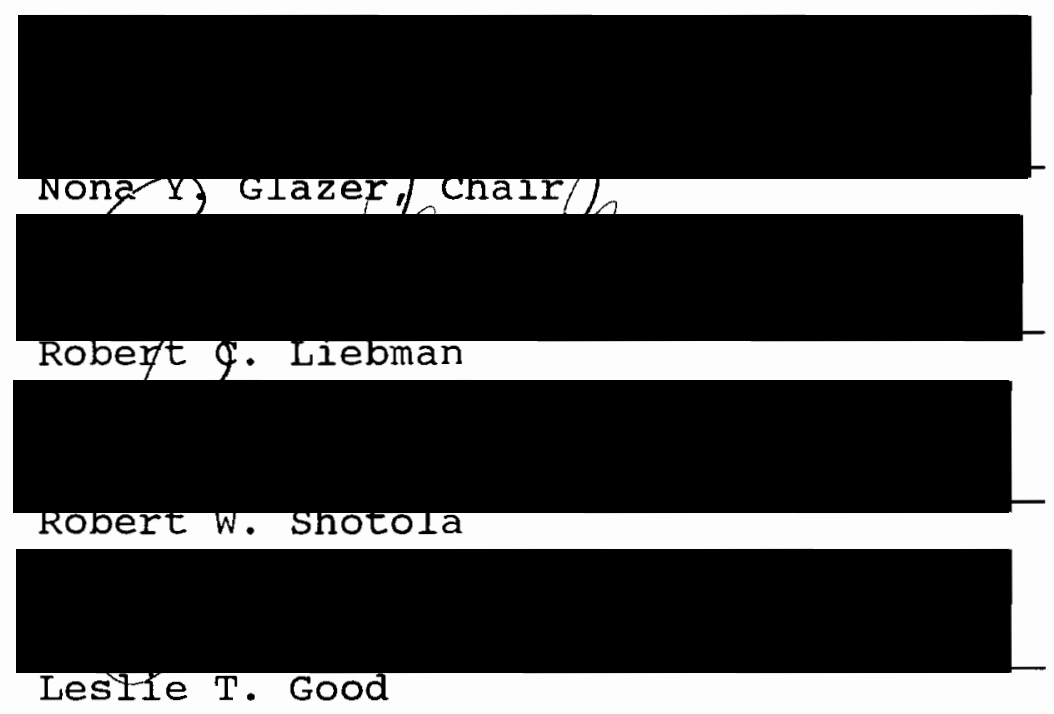

APPROVED :

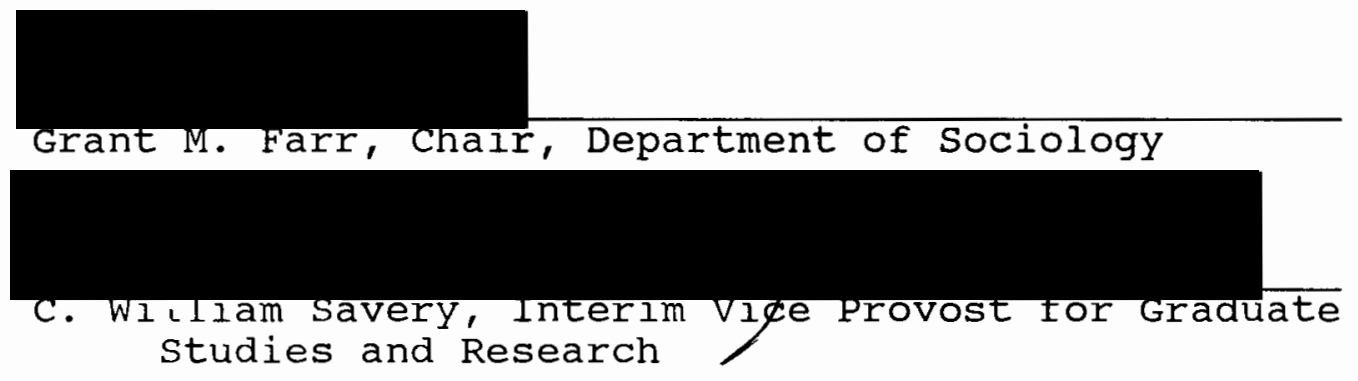




\section{DEDICATION}

This thesis is dedicated to

Aaron Hood-Brown.

He knows why. 
ACKNOWLEDGEMENTS

I would like to thank my thesis committee; Nona Glazer, Robert Liebman, and Robert Shotola; for guidance, ideas and advocacy both during my thesis research and in my classes at PSU. Their expertise and assistance has been invaluable, and has greatly influenced my own work. I would also like to thank Leslie Good for her interest in my work and her encouragement. I would like to thank Stephanie Limoncelli for moral support, for sound advice, and for sharing an intellectual common ground; and Fiona Martin, for countless discussions and friendly arguments. 
TABLE OF CONTENTS

PAGE

ACKNOWLEDGEMENTS....................... iii

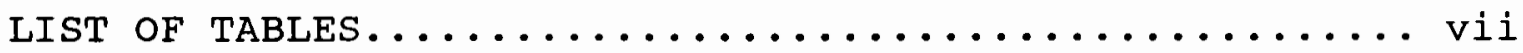

CHAPTER

I INTRODUCTION ..................... 1

II THEORETICAL BACKGROUND.............. 5

Gramsci and Hegemony.............. 5

Ideology and Classical Marxism

Gramsci and 20th Century Capitalism

Hegemony vs. Ideology

Domination by Consent

Changes in Hegemony

Hegemony and the Press

Alternative Hegemony and Democratic struggle

Kerbo and Perspectives on Poverty....... 13

Individual Responsibility

Cultural Deprivation

Situational Factors

Structural Causes

Perspectives on Poverty and Hegemony

III LITERATURE REVIEW................ 22

Hegemony in News Texts............ 22

The Media and Social Action......... 29

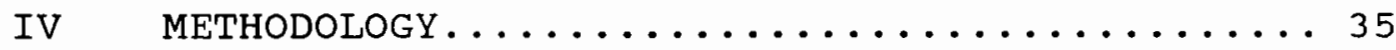


The "Great Society" Years vs. the Post-

Reagan Era................ 35

The "War on Poverty"

The Policies of the Reagan Era

The state of Oregon and the Two Eras

Sampling strategy.............. 46

Conceptual Frames............... 47

The War on Poverty Frame

The Reagan-era Frame

Cultural Themes

Challenges to the dominant frames

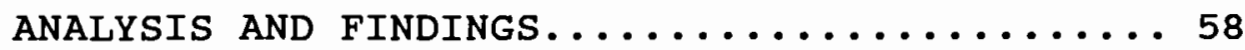

Relationship of the stories to the

Dominant Frames.............660

Stories Which Support the Frames

Stories Which Accept the Frames

Stories Which Present Co-opted

Challenges to the Frames

stories which Present Challenges Which are Not Co-opted

Differences in Emphasis, 1969 vs.

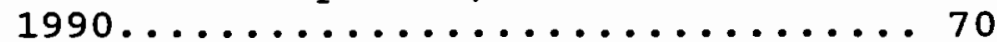

Exemplary Language............. 75

Language in the 1969 Newspapers

Exemplary Language in 1990

Major stories................. 83

VI CONCLUSIONS AND SUGGESTIONS FOR FURTHER

RESEARCH...................... 93

SELECTED BIBLIOGRAPHY...................... 102

APPENDICES

A NUMBERED LIST OF STORIES IN THE SAMPLE, BY HEADLINE........................... 106 
B LISTS OF SPECIFIC STORIES REFERRED TO IN

TABLES I - VII................ 116

C MAJOR STORIES, LISTED BY HEADLINE......... 124 


\section{LIST OF TABLES}

TABLE

PAGE

I Relationship of stories to the dominant

Frames...................... 61

II More stories from 1969 than 1990 Mention

Race........................ 70

III Stories Exclusively from 1990 Mention

Homelessness, Substance Abuse, and

Mental Illness.................71

IV More Stories from 1969 than 1990 Discussed Government-Sponsored Antipoverty

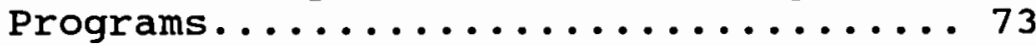

V More stories from 1990 than 1969 Discuss

Charitable or Non-profit Sector

Antipoverty Programs.............73

VI Stories from 1969 and 1990 Present the

"Humanity First" Theme Almost

Equally often.................. 74

VII More stories from 1990 than 1969 Present

the Voluntarism/Charity Theme....... 75 


\section{CHAPTER I}

\section{INTRODUCTION}

In my research I identify how messages about poverty in two mainstream oregon newspapers from two contrasting historical eras change but remain congruent with the interests of the dominant class in the capitalist United states.

The concept of hegemony, which can be loosely defined as cultural dominance, is central to my work. The hegemony of the capitalist class contributes to commonly-held definitions of reality which support, or at least do not challenge, the agenda of the dominant class. The cultural apparatus, the individuals and institutions that produce culture, promotes a worldview largely consistent with the interests of the dominant class. Definitions of reality as well as "common sense" disseminated by the cultural apparatus are internalized by intellectuals and the working class, resulting in domination by consent as well as by coercion (Boggs, 1984).

One of the basic principles of Antonio Gramsci's theory is that the hegemony of the dominant class must change to both reflect and absorb the effects of social change if the legitimacy of the dominant class is to remain unchallenged by contradictory definitions of reality. If hegemonic relations change to accomodate new events and information, contradictory 
definitions of reality are neutralized. This is what makes hegemony effective in preserving relations of domination.

The two mainstream oregon newspapers I examine are part of the cultural apparatus of this capitalist society. Newswriters, editors, and the news sources quoted in stories present differing views on class relations, which may challenge or validate the hegemony of the corporate class. The news producers determine which viewpoints will be presented and what form the presentation will take, and thereby shape social consciousness. News stories illustrate hegemonic practices.

The cultural messages produced by newspapers may change to reflect historical context. I have sampled messages from two very different historical eras, the period following Johnson's "War on Poverty" and the period following the Reagan administration. I examined differences in the causes of and solutions for poverty stated and implied in stories from both eras, and I looked for evidence of underlying cultural themes which suggest a moral stance.

Although I have hypothesized that messages about the poor will change from one time period to the next, I did anticipate that some aspects of the messages will remain constant. I began with the assumption that stories would not present a cause of or solution for poverty consistent with a structural causes perspective without co-optation in either time period, as to do so would be a challenge to the hegemony of 
the corporate class. I expected that the qualities of the poor themselves would receive more attention in these mainstream newspapers than possible structural causes of or solutions for poverty. I also anticipated that the messages about the poor presented will be compatible with the goals and policies of the high-level politicians in office in both time periods.

My analysis revealed that the messages about poverty from 1969 stressed a "cultural deprivation" perspective, and most often discussed race in connection with poverty. The stories from this era also focused on government-sponsored antipoverty programs. The stories from 1990 most often gave "situational factors" explanations for poverty. The messages from 1990 focused on the working poor and the homeless rather than a minority underclass, and de-emphasized race. The 1990 stories placed more emphasis on charity and non-profit sector agencies, rather than government programs, providing antipoverty services.

Four out of sixty stories in 1969 presented information and viewpoints that challenge the dominant class's conceptualization of poverty and are not co-opted by the news production practices. In 1990 there were six such challenges in a sample of sixty stories. These challenges illustrate the expansive quality of hegemony. I initially assumed that a story specifying a cause of and solution for poverty consistent with a structural perspective presents a real 
challenge to hegemony. I conclude that this assumption was in error. Some stories do present viewpoints which are consistent with the structural causes perspective on poverty, but do not present the structural causes perspective in its entirety. A story can present information or quote sources that cite the economy as the cause of poverty, yet fail to convey that poverty is endemic to capitalism. A reader who has not been sensitized to the structural perspective may interpret this information in a way that is consistent with the conceptualization of poverty promoted by the dominant class. The reader may surmise that the present (and perhaps seemingly aberrant) state of capitalism is the cause of poverty, rather than concluding that capitalism itself inevitably causes poverty. Challenges to the dominant class's conceptualization of poverty, then, may be co-opted by omission of key elements of a structural argument, as well actively co-opted by various journalistic practices. 
CHAPTER II

THEORETICAL BACKGROUND

GRAMSCI AND HEGEMONY

\section{Ideology and Classical Marxism}

Marx believed that there are two levels of social reality, the base and the superstructure. The base, which includes the social relations of economic production, is the foundation from which the superstructure develops. The superstructure includes the state in a society as well as social consciousness; religion, education, culture, and political and legal systems are all included in the superstructure. As the superstructure develops out of the material relations of the base, the state and social consciousness will reflect the economic system. This is not to say that economy is the sole determinant of all social reality for Marx, although material relations are of primary importance.

The superstructure is a domain of struggle wherein the economic classes compete to determine politics and to legitimate definitions of reality which serve class interests. In capitalism, the property-owning bourgeoisie dominates the superstructure because they dominate the economy and can 
thereby subsidize the activities of members of the cultural apparatus. The dominant class depends on the superstructure as well, as this is the domain of ideological production. Ideology, or social ideas about what is good, moral, worthwhile and natural, reflects and protects the interests of the bourgeoisie in a capitalist society.

Marx believed that the working class acts according the interests of bourgeoisie because of bourgeoise ideology. The working class must overcome bourgeoise definitions of reality in order to develop "class consciousness". Class consciousness includes a sense of group identity based on economic class, a realization that oppression is due to class relations, and that action can and should be taken to change material relations. Marx thought that as more wealth becomes concentrated in the hands of a smaller and smaller bourgeoisie, the large and increasingly impoverished working class will see the contradictions between the dominant ideology and material realities. They will develop class consciousness, revolt, and change economic relations. When the relations of production change, change in politics and social consciousness will follow.

Gramsci and 20 th century capitalism

Antonio Gramsci, an Italian Marxist writing in the 1920's and 30's, noticed that some of Marx's speculations had not borne themselves out in the capitalist societies of the twentieth century. Although wealth had been consolidated into 
fewer and fewer hands in many advanced capitalist countries, he saw no indication that any sort of revolutionary consciousness was developing among the working classes of those nations. In fact, he perceived a decline in class identity, and a tendency toward reformist rather than revolutionary politics among workers (Boggs, 1984: 153) Although Marx believed that the concentration of wealth under the control of an ever-shrinking bourgeoisie would spur the growing and increasingly oppressed proletariat to revolt, Gramsci observed that advanced capitalist societies were in fact extremely stable.

Hegemony vs. ideology

Marx believed that ideology was a distorted reflection of the material relations of capitalism. Gramsci, in contrast, rejected the division between base and superstructure, instead asserting that ideological elements present in culture have material consequences in how they compel individuals to act in relation to economy (Boggs, 1984: 158). Ideology serves as motivation in the economy; therefore the base and superstructure are inseparable in capitalism. For Gramsci, the superstructure does not mere]y express the relations of the base, but is inseparable from them (Williams, 1977). The participants in material relations are motivated in part by ideology, and behave according to the definitions of social reality they have been given by the superstructure. For example, a worker in a capitalist society may produce as much 
as possible at work even though her rewards will not reflect her effort, because the Protestant work ethic tells her this is the moral and proper way to behave. She does not question this arrangement because the work ethic is a central assumption in her definition of reality. Gramsci's interpretation of the relation between base and superstructure is especially relevant in capitalist societies of the present day, where production of services and information, rather than material goods, makes up the majority of economic activity. The ideology of the superstructure intrudes easily into economic production of this kind, as it appears not only as a motivational force, but as part of the product.

The notion of hegemony in Gramsci's Marxism is a refinement and elaboration on the classical Marxist concept of ideology. Marxist ideology is an abstraction of lived social relations, and is articulated and formalized; hegemony, in contrast, constitutes and is constituted by lived social relations and is in large part unarticulated and unconscious. Ideology is the product of power relations, whereas hegemony includes power relations. Hegemony is not just the manipulation or indoctrination of members of society; in fact, hegemony defines all of reality for social actors (Williams, 1977: 110). Because of the complex and broad-ranging nature of hegemony, it is difficult to define in a few words.

Hegemony is... a whole body of practices and expectations, over the whole of living: our senses and assignments of energy, our shaping perceptions of ourselves and our world. It is a lived system 
of meanings and values... which as they are experienced as practices appear as reciprocally confirming. (Williams, 1977: 110)

Hegemony is the product of an historical moment when all aspects of social life work in concert to protect and further the interests of the dominant class (Mouffe, 1988).

While Marx believed that economic conditions would lay bare the contradictions inherent in the dominant ideology and lead to revolution, Gramsci believed that such economic crisis would be a necessary but insufficient cause of insurrection. Gramsci did not completely reject economic relations in his work; he asserted that hegemony plays a part in shaping economic relations in addition to being shaped by them. For Gramsci, revolution will only occur when contradictions become apparent in all levels of social life, and when the working class can successfully construct an alternative hegemony of its own. Revolution can happen only with the end of the consent of the dominated, and will be followed by the formation of a new hegemony. This new hegemony will not include the power relationships, definitions of reality or social practices found in capitalism, and will instead serve the interests of all members of society.

Domination by consent

Classical Marxist theory focuses primarily on explicit coercion as the means of control available to the dominant class. Gramsci, on the other hand, emphasizes the importance of domination by consent as the result of the hegemony of the 
capitalist class. Gramsci argued that

...no social order could sustain itself over the long run primarily on a foundation of organized state power, that on the contrary the inclination of a ruling class to rely upon repression and violence was a sign of weakness rather than strength. What contributed to real political durability was the scope of popular support or ideological consent. (Boggs, 1984: 159, emphasis in the original)

Hegemony, in order to be successful, must be deeply embedded in the subjectivity of the members of society. When internalized, hegemony becomes "common sense," "the traditional, popular conception of the world" (Boggs, 1984:

161). As common sense hegemony is powerful, more powerful than any material apparatus of coercion. Hegemony

...mystifies power relations, public issues, and historical events; it encourages fatalism and passivity toward political action; it justifies various types of system-serving deprivation and sacrifice; (and)... works in many ways to induce the oppressed strata to accept or "consent to" their own daily exploitation and misery. (Boggs, 1984: 161)

Domination by consent is unique to capitalism. In precapitalist societies the state did strive for hegemony, but only in capitalist societies can the state fully impose its hegemonic position on civil society. Hegemony can be viewed as the mediator between the state and civil society in capitalism (Sassoon, 1982: 100).

Changes in hegemony

Although he believed domination to be achieved by consent, Gramsci did not believe hegemony to be all-pervasive 
or monolithic. Hegemony, by virtue of its complexity, is always in a state of disequilibrium of varying intensity. As social conditions change, new information appears which may contradict the precepts of hegemony. To endure, hegemony must change to eliminate the possibility of contradictory social practices or definitions of reality. The dominant culture prevails "...only by absorbing and domesticating conflicting values, definitions of reality and demands..." (Gitlin, 1980: 256). Hegemony incorporates new information and dissenting viewpoints. Views critical of class relations are presented, but are transformed so as to be consistent with dominant class interests. Critical views are "co-opted" (absorbed into or assimilated by the content of hegemony), or neutralized.

\section{Hegemony and the press}

The mainstream press, as part of capitalist hegemony in late capitalist America, plays a role in mystifying social and political life. The media serve as sources of information to which individuals may turn when lacking direct, experiential knowledge (Gamson, 1990; Gitlin, 1980). Although the working class may see the effects of macro-level economic conditions on their own lives and the lives of others they know, personal experience alone, without an interpretive system, does not result in an understanding of class domination and what can be done to change it. The mainstream media present a distorted understanding of class relations which does not suggest that capitalism is the root cause of 
many social problems. News producers treat the imperatives of the capitalist system as natural, inevitable and proper. The members of the cultural apparatus will not, therefore, present social problems such as poverty as endemic to the capitalist system, or endorse solutions which would alter power

relations. Additionally, because the content of hegemony must incorporate and domesticate new and oppositional ideas, the picture of poverty in the media must change to reflect social and historical context.

\section{Alternative hegemony and democratic struggle}

In order to effect change in the relations of power, an alternative hegemony must come into being, but not all types of alternative hegemony will bring social change that will benefit the working class as a whole. Change in class relations requires an "expansive" (Mouffe, 1988: 103) hegemony which links all struggles for democracy together, recognizing the struggle of one subordinate group as the struggle of all. Although many groups criticize economic realities, economic relations are polysemic: they can be interpreted in more than one way, depending on the perspective of the interpreter. Chantal Mouffe (1988: 96) cites stuart Hall's analysis of "Thatcherism" as an example of alternative hegemony which does not recognize the universality of struggle among oppressed groups. She notes that under the Thatcher administration many British workers had identified working women and immigrants as the cause of their unemployment and 
economic hardship, instead of pinpointing the Thatcher administration or the British economic system as the root of the problem.

Alternative hegemony also forms in the United States, as groups within the working class strive to understand the conditions of hardship in which they live. In recent years many groups have been singled out as the cause of economic and social troubles by various groups in the working class: New Right activists point to working women as the cause of unemployment among men (Faludi, 1991); white supremacist and neo-Nazi groups consider people of color and Jews to be the guilty parties in the economic decline of white, Christian Americans (Flynn and Gerhardt, 1989). From the Gramscian perspective, until an expansive hegemony which recognizes the universality of the struggles of all members of the working class and other oppressed groups comes into wide acceptance, the energy of the people will continue to be drained by scapegoating efforts and class relations will not change.

KERBO AND PERSPECTIVES ON POVERTY

Harold Kerbo (1983) notes that various theories and perspectives explaining the existence of poverty have been formulated and accepted in the last century. Paraphrasing Kerbo's discussion, I call these perspectives "individual responsibility," "cultural deprivation," "situational factors," and "structural causes". Only the structural causes 
perspective examines the structure and imperatives of capitalism as a major cause of poverty, and recognizes that poverty is therefore endemic to the capitalist system. As a researcher I take the structural causes perspective because I consider the other three to be part of the ideology used by the ruling class to maintain its hegemony. I will use the structural causes perspective as a vantage point from which to examine the messages in the mainstream press.

\section{Individual responsibility}

This perspective identifies the moral character of poor individuals as the cause of their poverty. Moral defects of the poor, such as laziness, stupidity, and corruption are considered to be the cause of poverty, and consequently the proper solution to the problem of poverty is compel the poor to stop being lazy, stupid or corrupt and work for a living. The popularity of this perspective, Kerbo notes citing many studies, persisted from the colonial era into the 1970's. In fact, Kerbo (1983) refers to this perspective as the "popular" viewpoint on poverty. Adherents of this view argue that welfare and social services are unnecessary and undesirable unless for the benefit of those who absolutely cannot work for a living, such as children, the very old, and the disabled or infirm. The proper solution for impoverishment among the "able-bodied" is for the state or community agencies to compel them to work. This perspective has strong roots in the individualist tradition of the United States, which stresses 
equality, competition, the importance of the individual over the group, and "laissez faire" government policy (Kerbo, 1983: 300) .

\section{Cultural deprivation}

This perspective points to a deviant culture among the poor as the cause of continuing impoverishment. It is based on the notion of a "culture of poverty," a commonly-held notion among policy-makers in the 1960's (Rainwater and Yancey, 1967 and Zarefsky, 1986) and is typified by the book Five Families (Lewis, 1959).

The culture of poverty develops as a result of economic conditions. The conditions of poverty present the poor with unique challenges, which cause them to adopt a unique lifestyle adaptive to poverty. This lifestyle includes common values, attitudes and behavior which are institutionalized as a subculture that is not suitable for existence outside of poverty. This subculture is then transmitted generationally to the children of the poor through socialization. Because the poor are socialized to have different values, attitudes and goals than middle class people, they will not take advantage of opportunities to improve life conditions when those opportunities present themselves (Kerbo, 1983: 306).

Because they have been socialized into a deviant subculture, the poor are alienated and marginal. They are unable to delay gratification or plan for the future. The poor are tolerant of deviant family structures, including 
families headed by unmarried or single parents. Additionally, the poor rarely participate in many social institutions, with the exception of the welfare and criminal justice systems (Kerbo, 1983: 306).

Although the cultural deprivation perspective recognizes that economic and political realities do contribute to poverty, the deviant subculture of the poor receives most attention from this perspective in both explaining and offering solutions for continuing poverty. The solution to poverty must be to resocialize the poor into the culture of the non-poor. When the poor learn how to behave like the nonpoor and internalize the proper values, they will be able to take advantage of opportunities and pull themselves out of poverty.

\section{Situational factors}

This perspective takes political and economic factors into account to a greater extent than the individual responsibility and cultural deprivation perspectives, yet does not indentify the imperatives of capitalism as the cause of poverty

Situational factors theorists assert that the poor do not have different values than the non-poor, but the hopeless conditions they face lead the poor to set aside some of those values and act in a manner which is more realistic given their life circumstances. Economic conditions such as rising unemployment and recession cause poverty, which in turn 
affects the behavior of the poor. The poor may therefore exhibit deviant behavior, such as substance abuse or criminal activity, in spite of having basically the same attitudes, values and goals as the non-poor. The important difference which separates this perspective from that of cultural deprivation is the rejection of the idea that the poor have a deviant subculture responsible for perpetuating poverty. The situational factors perspective is similar to cultural deprivation in its attention to the qualities of individual poor people, although for situational factors theorists this emphasis is important primarily as a means of disproving the tenets of cultural deprivation theory (Kerbo, 1983: 310).

The solution to the problem of poverty is to change economic conditions by promoting economic expansion and creating more opportunity for employment. When the poor can find jobs and generate an income, they will discontinue any deviant behavior they may have engaged in while poor.

\section{Structural causes}

Structural theories of poverty recognize that poverty is a natural by-product of the capitalist system, and it is necessary for the smooth operation of that system. This perspective challenges the dominant notion that capitalism is inevitable, natural, and always beneficial.

Kerbo identifies several factors involved in capitalist economic structure which contribute to poverty. The different types of occupations in late capitalism are central to the 
structural causes position. The poor are found mainly in jobs that require minimal skills and pay low wages and often lose their jobs due to increasing mechanization in industry. The poor are also disproportionately found in service-sector jobs which offer little job security and are not unionized. Because the poor own no material assets, they are left with no source of income if a job is lost.

Cycles of economic "boom and bust" are endemic to a capitalist system, and these cycles are normal and inevitable. The poor are useful for capitalism because they form a "reserve army of labor" which employers can fire in times of economic contraction and re-hire in times of economic expansion.

Finally, the capitalist imperative for expansion and accumulation of wealth contributes to poverty. This is evident in the shift from labor-intensive to capital-intensive (mechanized) industry, a frequent cause of unemployment among industrial workers. Since the 1960's desire for higher profit has also motivated corporations to move operations to countries where labor is cheaper, and where the labor force is more easily controlled. This capital flight results in unemployment among workers in the United States and undermines the local tax base; corporations no longer pay taxes in this country, and the unemployed workers are not earning as taxable an income. This is particularly true in areas once dominated by one industry. Manufacturing jobs lost are often replaced 
by lower paying, less stable, and non-unionized service sector jobs.

Because the cause of poverty is the structure of the corporate capitalist system, the solution for poverty must also be structural. The capitalist system must at least be regulated more than it is now, if not eliminated, in order for widespread poverty to disappear. Changes must be made in the economic and legal spheres which will prevent corporations from acting without regard to workers.

Many structural theorists recognize that although the welfare system is useful in providing aid for the working class, it does not address the causes of poverty. The welfare system does provide an alternative to jobs paying very low wages as well as an income for striking workers. The welfare system also helps allow children to attend school rather than working for a wage. The system, however, has disadvantages for the working class. The welfare system can serve as a means of social control by changing eligibility requirements and manipulating the reserve army of labor, and increases in welfare benefits can also be used to co-opt dissenting social movements (Piven and Cloward, 1971): policy makers may offer more welfare to appease a movement, but ignore its demands for changes in class relations.

\section{Perspectives on poverty and hegemony}

Gramsci believed capitalist class hegemony in the United States to be particularly strong, as the United states had not 
experienced a feudal stage. This culture developed from its inception on the ethical principles of capitalism, including the Protestant work ethic and the spirit of individualism (Boggs, 1984). The material relations of capitalism have always been present in this country as well. The individual responsibility perspective is one of the central themes in American social life.

Theories of cultural deprivation do not challenge the capitalist hegemony as these theories suggest changes in the socialization of the poor as the solution to poverty. The situational factors position, while considering realities beyond individual qualities, presents no challenge; a mystified and reified economy is identified as the cause of poverty, and the solution lies in vague plans to "create more jobs". The basic structure of capitalism is immune to criticism and change. These theoretical positions as well as the individual responsibility perspective are likely to be invoked by those writing accounts of poverty in mainstream newspapers.

The structural theoretical perspective alone presents a challenge to capitalist hegemony. This position rejects that capitalism is natural and right, and prescribes regulation of economic activity, if not changes in class relations, as the remedy for poverty. For this reason, the structural causes perspective will not often be presented in mainstream newspapers, unless structural arguments are restated or 
manipulated so that they appear to be consistent with the hegemony of the dominant class. 
CHAPTER III

\section{LITERATURE REVIEW}

Much recent research has investigated the ways in which newswriting and production practices contribute to hegemony. These studies suggest that the strategies employed in producing news texts are often unconscious and usually quite subtle. One of the least noticed and most effective strategies is the journalistic code of "objectivity" itself. Studies also suggest that media coverage shapes public perception of social movements and can affect the course of social action.

\section{HEGEMONY IN NEWS TEXTS}

Steven Gorelick (1989) analyzes the content and language of "crimefighting campaign" in the New York Daily News, and concludes that this newspaper presents crime and possible solutions for it in a way that serves the hegemonic interests of the dominant class in our society. Specifically, Gorelick points out that although the Daily News claimed to be presenting the realities of crime and offering solutions for it, the picture presented was inaccurate and the solutions presented largely violent, personal defense measures. He found that much more attention was given to relatively rare, 
dramatic violent crimes such as murder, armed robbery, and muggings than was given to frequent but more mundane crimes such as auto theft. He notes that the language in the newspaper depicted the crime problem as an impending natural disaster or a spreading disease, which he interprets as a justification for violent actions on the part of police and potential victims who must fight crime. Such depictions, he argues, make crime appear incomprehensible, apocalyptic, and unstoppable. Nothing can be done to stop crime, so citizens must take violent action to stop individual criminals. This, he concludes, absolves those in power from adopting programs and strategies aimed at changing the structural realities (such as poverty, joblessness, underfunded schools) that contribute to crime.

Condit and Seltzer (1985) explore the journalistic "code of objectivity" and how it shapes public awareness of events and social issues. They argue that this code is the product of behaviorist standards of "ohjectivity," which state that only that which is empirically verifiable is objective. They compare the court transcripts of a well-publicized murder trial with the coverage of that trial in the local newspaper, and conclude that the story toid in the newspaper was biased in favor of the prosecution.

In a trial, they assert, the prosecution is responsible for showing how the defendant had broken the law, and the defense attorney is responsible for making sure that the 
rights of the defendant are protected. The law, which is articulated and specific, is more compatible with journalistic objectivity than the nebulous concept of "rights." It is often fairly easy to ascertain that the actions of the defendant were in violation of the law, particularly in the case condit and seltzer examine. The actual circumstances surrounding the actions of the defendant as well as his or her subjective reality is not presented in the journalistic account, as this phenomenological information is not compatible with behaviorist "objectivity:" it is not empirically verifiable. In spite of the "open and shut" appearance of this murder case as it was presented in the newspaper, the defendant was acquitted due to testimony which illustrated his situation and subjective reality. The picture of the case seen by the jury, which included subjective information, was very different than that seen by the readers of the local paper, and because of this the jury was much more sympathetic than the news audience.

Condit and Seltzer also note that when the events of the trial were reported in the media out of context they took on a bizarre and sensational tone. Without offering information about the religious background and character of the defendant the newspaper reported that he considered the man he murdered to be possessed by demons. The jury was able to put this bizarre detail into context but the news audience was not. 
This did not enhance the defendant's credibility outside of the courtroom.

Condit and Seltzer conclude that the newspaper coverage presented a picture that was biased in favor of the prosecution because the journalistic code of objectivity is compatible with prosecuting strategy: to get to the verifiable "facts" and to determine that the clearly specified law has been violated. The rews media do not present a picture of events that is friendly to the defense because the defense is concerned with stowing the jury the subjective reasons why the defendant acted as she or he did. Journalistic accounts, therefore, will be biased in spite of the code of objectivity, because the code itself is inherently compatible with only institutionalized and formal perspectives. The institutionalized and legitimated account will be treated more favorably than the stories of individuals. This is vital in creating and maintaining hegemony •

Klaus Bruhn Jensen (1987) analyzes network television news broadcasts and observes that there are some basic strategies and conventions common to seemingly diverse news stories. Certain presuppositions are implicit in news texts. These ideas represent what is assumed to be "common sense" and therefore not in need of articulation, for example: the legitimacy of authorities, the democratic system and capitalism. These presuppositions are evident in what is 
stated in the news story and in what is not stated; the social actors not present, the ideological stance not mentioned, the potential sources not quoted. The writer's arrangement of elements in the story and choice of quotes from news sources further reveal the ways in which he or she conceptualizes the issues reported. Coherence in a story is achieved through the use of syntactical structures as well as through "the functional relations between sentences that allow us to identify a sentence as giving a cause or effect, a conclusion or a substantiation of an argument" (Jensen, 1987: 11). Jensen asserts that many news texts on the economy rely on "noninformation" such as isolated statistics, which are meaningless without explanation of the realities they represent. These "non-explanations" for economic realities nonetheless sound very official and like they should be meaningful .

Most importantly; Jensen observes that society is presented as "a system of autonomous spheres" (1987: 8) wherein the economy and politics are independent. When the economy is discussed in the news, it is described as having a momentum all its own: interest rates "go up," inflation "skyrockets," with no mention of actual social realities or actors which cause these things to happen. Political stories focus on the action and proposals of individual politicians, public figures and political institutions, portraying politics as a formalistic game without reference to the real-life 
consequences of these actions. Politicians are treated as responsible for maintaining an environment in which the economy can function on its own, yet news stories do not suggest that these politicians effect economic change which in turn affects the lives of citizens. He observes that one of the most basic features of all the news stories in his sample is the separation of "the coverage of economic fluctuations from the coverage of the political institutions that supposedly serve to control these fluctuations" (1987: 12). I argue that this technique used by reporters is instrumental in maintaining hegemony, as the separation of economy from politics eclipses the responsibility of political leaders for the economic well-being of their constituents.

Campbell and Reeves (1989) examine the network television coverage of, as well as a "60 Minutes"'documentary on, the case of a New York homeless woman, Joyce Brown, who was institutionalized against her will. They note that the euphemism of "homelessness," which implies involuntary poverty, has replaced "vagrancy," which implies voluntary poverty, in the news coverage of the 1980's. They point out that increases in joblessness, decreasing social services, and urban gentrification have contributed to a rise in homelessness in the $1980^{\prime} \mathrm{s}$, and this reflected in the change in language. In spite of this linguistic change, however, news texts still present a picture of homelessnes which does not include capitalism as its cause. 
Campbell and Reeves argue that the network news coverage of the Joyce Brown case distanced the audience from the homeless, by defining the homeless as "other." These news stories used legitimate "experts" as their sources, and did not present the subjective reality of the homeless themselves unless to show the homeless as insane speakers of "nonsense" (Campbell and Reeves, 1989: 23). The function of news discourse, they argue, is to re-incorporate the logical and coherent sense of experts as well as the nonsense of the homeless into the "common sense" of the audience, which has no frame for understanding homelessness as caused by the actions of the powerful. The news stories present the homeless as illogical and mentally ill, thereby separating homeless individuals from structural causes of poverty and from the rest of society.

The "60 Minutes" expose differed from the network news coverage in that this story presented Joyce Brown's perspective, allowing her tell her own story and to explain why she behaved as she did. This painted a more sympathetic and sane portrait of Ms. Brown, portraying her as an individual rather than as part of the nameless mass of homeless people. Ms. Brown's own viewpoints may challenge the hegemony of the capitalist class, but those shown in the program did not. The story distanced the audience from the homeless, and distanced Joyce Brown from other homeless people as well. She was permitted to tell her story, but much of 
that shown in the broadcast story consisted of explanations of how she was not like the rest of the crazy homeless. The story "personalized" the issue of Joyce Brown's homelessness and separated it from the structural context of homelessness in general, and turned her struggle into a personal conflict with the mayor of New York City instead of an issue of class conflict. Additionally, President Reagan then later responded to this story by erroneously portraying Ms. Brown as a woman who wanted to be homeless. Although she preferred homelessness to institutionalization, she preferred permanent housing to homelessness (Campbell and Reeves, 1989: 40).

Campbell and Reeves, and I, too, believe that by distancing the impoverished from the rest of society and by attributing the cause of homelessness to mental illness rather than structural realities, producers of news serve the interests of the hegemonic class. This strategy excuses those in positions of power from finding and adopting structural solutions to the problem of homelessness. The audience will also excuse leaders from responsibility if they incorporate this perspective into their stock of "common sense."

\section{THE MEDIA AND SOCIAL ACTION}

Todd Gitlin (1980) investigates the relationship between the media and the "New Left" movements of the 1960's, and concludes that the media played a crucial role in shaping them and in their demise. The media present an unsympathetic 
and distorted picture of social movements that challenge capitalist class hegemony, and this can undermine both external support for the movement as well as participant loyalty.

Gitlin notes that the "narrow social base" of the New Left made it dependent on the media to get its message out to the general public because the young intellectuals and college students who composed it seldom came in contact with groups unlike themselves in American society. The commitment of the New Left to broad goals such as ending the Viet Nam war and students' rights led it adopt revolutionary rhetoric in spite of a non-revolutionary agenda. This made news writers see New Left activities good news copy and worth bringing to the attention of the media audience. Social movements which the media producers perceive to be revolutionary rather than reformist are portrayed as deviant, and although this attracts the attention of the audience, it does not enhance credibility or legitimacy. Emphasis on the movement's revolutionary rhetoric associated it with other movements with revolutionary agendas, all unpopular and viewed as "anti-American" by many newswriters and by the media audience. The New Left appeared a "spuriously amplified" (1980: 285) threat, the target of ludicrously exaggerated backlash on the part of conservatives in American society.

Gitlin argues that the movement itself was shaped by the coverage it received. The diverse movements of the New Left 
had no clear guidelines for determining what qualities were necessary in movement leaders. The media, always searching for interesting news copy, zeroed in on the most vocal and flamboyant figures in the movement, transforming these individuals into celebrities. Tempted by celebrity and notoreity, the some leaders acted according to their own desire for fame, ignoring the desires of others in the movements, and the causes the movements espoused. The New Left, lacking a defined ideology or organizational structure, had no mechanism for holding these individuals accountable. The movements lost participant loyalty when these leaders began to act in self-interest.

Gitlin believes the movenent grew less credible to the media audience and participants alike and became marginalized as a result of media coverage. He argues that

The more closely the concerns and values of social movements coincide with the concerns and values of elites in politics and in media, the more likely they are to become incorporated in the prevailing news frames. (Gitlin, 1980: 284)

If the agenda of a movement appears to challenge the hegemony of the dominant class, the portrayal of that movement in the media will not be sympathetic; the movement will be pictured as illegitimate and marginal, and may not be accepted by those outside of its ranks.

Gail Landsman investigates the Mohawk Indian/white conflict at Ganienkeh as an example of a marginal group using hegemony to advantage. The Mohawks manipulated cultural 
symbols and "reinvented" Indian traditions, thereby winning sympathy of whites and traditionalist Indians alike. This strategy, however, backfired as white sympathy was based on false perceptions and because attention was distracted from the mission of the Mohawk community. Landsman believes that, as Gitlin concluded, "media frames tend to become the movement" (Landsman, 1987: 101). She examines news coverage of the conflict in two newspapers, chosen because the audiences of these papers did not hear first-hand accounts of the incident from whites or Indians involved. These audiences would therefore be dependent on the news texts when forming an opinion. She looked for ways that the conflict, and the public's opinions about it, shaped and were shaped by media discourse.

Landsman notes that the initial coverage of the conflict was not sympathetic to the Mohawks, focusing on two violent and dramatic events. The Indians were characterized as participants in an uprising reminiscent of the incident at Wounded Knee. These "hard news" stories presented the views of legitimate authorities from outside the community at Ganienkeh. Later the conflict was the subject of several "human interest" stories. She points to popular notions in the 1970's which equated Indians with environmental conservation, as well as a growing interest in ethnic groups and traditional religions among many Americans, as reasons why the conflict received more sympathetic coverage in its 
later stages. The human interest stories, unlike the hard news stories, presented the subjective views of the Mohawks themselves.

The Mohawks at Ganienkeh presented their case in the human interest stories as an issue of Native American sovereignty, which appealed to Indian traditionalists, but is not easily understood by non-Indians. The Mohawks, although they had not signed the Treaty of 1974 which granted recognition of Native American sovereignty, aligned themselves with Iroquois nation (one of the six signing nations), which transformed the conflict into an international event. Treating the incident as an issue of sovereignty cemented traditionalist Native American support of Ganienkeh. At the same time, however, the press presented a romanticized picture of Ganienkeh, which appealed to urban whites. The Mohawks at Ganienkeh were aware of this appeal and used it to advantage, re-inventing and re-articulating Mohawk traditions. National sovereignty was tamed and presented by the Mohawks as an attempt to preserve "the old ways." A leader emerged, and was made a celebrity by the press. He began to "speak for" the entire community of Ganienkeh. This leader was a colorful figure who looked and behaved as the media audience wanted him to; he soon succumbed to the temptations of celebrity and fell from favor in his community.

The Mohawks were able to take advantage of the hegemony of white culture, yet the strategy backfired. Eventually the 
Mohawks came to be perceived as hypocrites by whites, as their lifestyle did not fit the romanticized ideal of the "traditional Indian." Whites believed that the Mohawks were not behaving like "real Indians" and that they had manipulated public sympathy fraudulently. The real issue, sovereignty, though never abandoned by the Mohawks, had been obscured by the romanticized notion whites had of Indian life. When whites discovered that this notion was an illusion, the Mohawks and their mission lost white support. The media had reframed the conflict in such a way that it presented no challenge to the sovereignty of the state, co-opting the goals of the Mohawk Indians by making these goals more palatable to white society. The hegemony of white culture in the United States was not challenged in these news stories. Both Gitlin's and Landsman's research demonstrate how conceptual frames disseminated by the media affect the course of social action. The definitions of reality promoted by the mainstream media serve the interests of the dominant class by shaping citizen's perceptions of issues and of what should be done to remedy social problems. The media often promote the notion that social action which does not challenge power relations is the only appropriate strategy. 
CHAPTER IV

\section{METHODOLOGY}

The content of hegemony must change in order to neutralize challenges to capitalist hegemonic definitions of reality. As historical context changes and new and possibly contradictory demands and definitions of reality appear, producers of hegemonic culture admit and co-opt them. New information is reinterpreted through hegemonic practices to make it compatible with interests of the dominant class. This process of reinterpretation is perpetual: while culture appears to change, core ideas supporting the existing power relations which underlie it remain constant. For these reasons I have chosen to examine messages from two very different historical eras, to investigate the expansive nature of hegemony as well as the constant class bias inherent in it.

THE "GREAT SOCIETY" YEARS VS. THE POST-REAGAN ERA

The "Great Society" programs of the Kennedy and Johnson administrations stand in contrast to the budgetary strategies of the Reagan administration. Change in human service program delivery that occurred in both the 1960's and the 1980's resulted from change in both political climate and economic conditions. The purpose of this thesis is to explore 
the ways these changes are reflected in the newspaper coverage of poverty in the two eras.

\section{The war on Poverty}

Political strategies in the late 1950's and the 1960's changed as a result of demographic changes. The migration of Black Americans from the rural South to northern industrial centers concentrated the Black community into substantial voting blocs in populous states with many electoral votes (Zarefsky, 1986; Piven and Cloward, 1971; and Haveman, 1977). The Democratic Party had won by a narrow margin in the 1960 presidential election; the votes of those key industrial states was crucial to future success of the party as were the votes of poor southern states which had broken with it. President Kennedy spoke often of implementing large antipoverty programs to resolve the fracturing of the Democratic Party.

When Lyndon Johnson took presidential office after the Kennedy assassination, he found himself faced with several political challenges. Johnson had been considered a conservative politician who protected regional interests, namely those of his home state of Texas. His expansion of antipoverty services was strategically valuable in demonstrating his commitment to continuing the liberal human service policies proposed by Kennedy, as well as in presenting himself as a national rather than regional politician (Zarefsky, 1986). 
Johnson held office at a time characterized by growing civil unrest in the cities in the form of riots and other kinds of civil disorder and disobedience. Many civil rights activists had begun working for economic as well as legal equity for people of color, even after the civil Rights Act of 1965 had been signed (Piven and Cloward, 1971). The Great Society, then, was not just a strategy for securing the Black vote as militant Black activists presented a threat to class relations which could not be ignored. Piven and cloward (1971) argue that the increase in welfare and human services during the 1960 !s was an effective means of co-opting the militant and disorderly activists. They arrive at this conclusion by examining the amount of federal aid allocated to key urban areas, noting that the areas with the most severe incidents of civil disorder received the greatest amounts of funds.

The dominant theme in conceptualizing and explaining the existence of poverty among government policy makers from this era was the "culture of poverty" thesis. This thesis is the foundation of the "cultural deprivation" perspective on poverty discussed in chapter II. The culture of poverty thesis identifies the poor as an underclass, usually nonwhite, who transmit cultural deficiencies generationally. Zarefsky (1986: 9) notes that to define poverty as a strictly economic issue would imply that economic measures would be necessary to eliminate the problem. It was politically safer 
for government officials to conceptualize poverty as a "lifestyle," and to direct efforts to changing the cultural arrangements of the poor themselves, than to treat poverty as an economic problem which can only be solved by redistribution of wealth. The war on Poverty included tax policies designed to benefit corporations, programs targeted at changing the qualities of poor individuals, and restructuring of the agencies through which the poor could gain access to jobs, goods and services (Haveman, 1977). These programs did not include any kind of effort to change the structure of the labor market; the focus was on making the poor more desirable for the jobs available.

The 1960's were characterized by economic prosperity and growing gross national product. The War on Poverty was feasible due to the comparative wealth of the country during this decade. The federal government had the revenue available and could sponsor antipoverty programs, and to do so was politically desirable. In light of the unrest in urban centers, the Johnson administration emphasized government-run antipoverty programs headed by "legitimate" experts (not radical antipoverty activists), as these experts could be trusted not to challenge the administration (Gitlin, 1980).

The largesse shown by the federal government in its antipoverty efforts did not benefit only the poor and the elected officials. The expansion of human services programs created a class of "helping" professionals, who supported the 
creation and continuance of programs on which their livelihoods depended (Haveman, 1977: 26; Piven and Cloward, 1971; and Funiciello, 1990). Daniel Patrick Moynihan noted the development of groups during this era who made a career of reform efforts, and commented on the tendency of the middle and upper classes to adopt policies designed to help the poor after serving their own interests (Funiciello, 1990: 38). The War on Poverty, ostensibly fought in order to increase the well-being of the poor, also created many jobs for the middle class professionals who administered antipoverty programs. The Nixon administration did not continue with Johnson's Great Society philosophy. The rhetoric of Nixon's New Federalism echoed the culture of poverty thesis in the causes of and solutions for poverty suggested, yet emphasized transferring the responsibility for these programs from the federal to the state and local levels. New Federalism was seen again in the Reagan administration, although with different causes of and solutions for poverty proposed.

The policies of the Reagan era

When Ronald Reagan took office in 1981 he found himself faced with very different economic challenges than did Johnson in the early $1960^{\prime} \mathrm{s}$. In contrast to the expanding and prosperous economy of the 1960's, the late 1970's were characterized by a seemingly paradoxical combination of rising inflation and sluggish productivity. Reagan sought to stimulate the economy while simultaneously decreasing the 
economic contribution of the federal government by adopting a series of policies.

Reagan supported "supply-side" economic policy; he argued that if corporations were presented with incentive to expand, they would do so and thereby create more jobs. The poor would be able to fill those jobs, and generate an income which could be spent and further boost the economy. The Reagan administration strategy included tax breaks for corporations and decreases in federal regulation of corporate practices (Palmer and Sawhill, 1984 and 1982) through the Economic Recovery Tax Act of 1981. This act was of course appealing to the wealthy and powerful corporate class.

Reagan decreased the contribution of the federal government to human services by shifting the budgetary burden from the federal to the state and local levels. This strategy, described by the administration as New Federalism, was quite similar to the New Federalism proposed by Nixon at the beginning of his administration. The omnibus Budget Reconciliation Act permitted an increase in defense spending while permitting large cuts in non-defense outlays; benefits were cut with the exception of those such as social security and short-term unemployment benefits, with many middle class beneficiaries who could influence Congress (Palmer and Sawhill, 1982: 383).

It was politically advantageous for Reagan to shift the burden of human service provision to the states and 
localities. The federal government was able to make tax cuts, while the local governments were fnrced to increase taxes in order to provide necessary services. Taxpayers may have perceived the federal government more favorably, as their federal tax payments decreased, and perceived their local politicians as villains for increasing taxes (Palmer and Sawhill, 1982). This shift also served to fragment groups who would lobby for increases in human services, as well as leaving the localities rather than the federal government open to tax revolt. If the citizens could not change federal budgetary policy, they could perhaps show their resistance to taxes in local elections. The federal government justified the cuts in funding to the state and localities with rhetoric of choice and freedom, and elected officials argued that these governments would be more in tune with the needs of their citizens than would the federal government. "Block grants" were issued to the states, with a decrease in funding for which the federal government allegedly compensated by removing restrictions on how the grants could be spent (Palmer and Sawhill, 1982: 170).

Finally, Reagan emphasized the spirit of voluntarism in his call for non-profit and charitable organizations to take on the burden of service provision abandoned by the federal government. This theme was echoed in George Bush's rhetoric in 1989: the "thousand points of light" and the "kinder, gentler nation." 
The shift in emphasis from government-sponsored to nonprofit sector human service programs ignored one crucial reality. Non-profit organizations rely on federal funding to carry out their missions; in fact, the federal government has historically purchased services from the non-profit sector. The Reagan administration cut the funding for these agencies at the same time expecting them to take on an increased case load, and, as a consequence, demand for services was not met (Palmer and Sawhill, 1982: 220). The shrinking social "safety net" as well as the shift from comparatively stable and well-paying manufacturing employment to unstable and lowpaid service employment has resulted in increasing poverty and homelessness over the 1980's.

The emphasis placed on charitable contributions by the Reagan administration was beneficial for corporations. Funiciello (1990) notes that by allowing corporations to deduct contributions to charities from their taxes without any limits or restrictions, corporations were able to unload undesirable merchandise without suffering financial loss. Much of the goods contributed to the poor are undesirable, unuseable, or not fit for consumption and therefore could not be sold on the market.

In the 1960's jobs were plentiful for middle-class citizens, especially professionals. During the 1970's and $1980^{\prime}$ s jobs for even skilled professionals became more scarce. Those who had formerly enjoyed good job security found 
themselves at risk of losing their jobs, particularly skilled blue-collar workers. The culture of poverty concept with its emphasis on a minority underclass no longer explained poverty, especially to the newly-poor white citizen. The policy makers of the Reagan era focused on situational factors in explaining poverty: economic realities like unemployment, the job market, interest rates, and so on. Reagan's economic policies, viewed from the situational factors perspective, seem reasonable and proper.

The state of oregon and the two eras

I have chosen to investigate the messages presented in Oregon newspapers in 1969 and 1990 for several reasons. I decided to use local newpapers rather than national publications to include local issues. National news stories written by both staff reporters and wire-service writers illustrate how news producers who cannot rely on experiential knowledge contribute to capitalist hegemony. The sample also shows how local writers and editors, who can rely on some first-hand knowledge of events, contribute to the hegemony of the dominant class.

Although 1969 is the first year of the Nixon administration and technically not part of the "Great Society," no significant changes had been made in the structure of human services in the state before that year. Prior to the 1969 legislative assembly, no large increases in funding for social services had been allocated, and the 
organizations of the social services department still included such Dickensian-sounding entities as "Orphans, Foundlings, and Wayward Girls." The 1969 legislative assembly restructured the social services department, calling it the "Department of Human Resources," and allocated more than double the previous amount of funding for surplus foods and welfare assistance. Programs were renamed with titles more similar to those of the progressive-sounding federal programs.

Although 1968 was an important year for politics on the state and federal levels, I did not choose 1968 precisely because it was an election year. I had some concern that news stories on poverty from that year might focus too much on election politics rather than the issue of generic poverty. Because 1969 was the first year of the Nixon administration, I anticipated that some of the news stories would present Nixon's New Federalism as an alternative to Johnson's Great Society philosophy. Although the New Federalist strategies for fighting poverty differ from the Great Society strategies, the conceptualization of poverty as a lifestyle remains constant. For this reason I do not believe that New Federalist messages are problematic for my analysis; in fact, the shift to New Federalism illustrates the expansive quality of hegemony.

The State of Oregon had made cuts in welfare spending in 1980, prior to Reagan taking office. This could be interpreted as an expression of political sentiment among 
Oregonians, rather than a response to federal policy (Palmer and Sawhill, 1982: 194), although the Carter administration mandated cuts in human service funding as well. In spite of state policies which reduced welfare to below minimum wage levels in 1980, the proportion of the state general fund budgeted for human services steadily increased each biennium through the $1980^{\prime}$ s, in small increments each legislative session.

The most dramatic indicator of political sentiment toward the poor and welfare in oregon did not appear until the 1990 state general election. The state of oregon has an accessible referendum system which has historically provided an outlet for various taxpayer protests. In 1990 a key ballot measure, Measure 7, passed in most counties in the state, including the populous Portland metropolitan area counties: Multnomah, Washington, and Clackamas. Although it passed by a narrow margin in those counties, this is somewhat surprising given the draconian policies it proposed. This measure proposed an "experiment," to be conducted in the six oregon counties in which it passed by the greatest margin, one of which was Portland's Multnomah county, the population center of the state. The measure would eliminate welfare, food stamps and unemployment insurance entirely. Those seeking public assistance would be required to participate in an employment program which would place them in jobs paying $90 \%$ of the minimum wage, with a full-time income of about $\$ 170$ per week. 
Applicants with special skills could be paid more, but all earnings above the base amount must be split with the program administration. The program did not allow for increased earnings to individuals with dependent children or disabilities, for day care assistance, or for health insurance, unless the state started programs to provide these types of assistance to all citizens.

The voting pamphlet rhetoric in favor of the measure was certainly in part responsible for its appeal. The sponsor of the Measure 7 waxes eloquent about the importance of working for a living and the sense of self-esteem gained therein in a paid section outlining arguments in favor of the measure. He refers to this measure as the "full employment" plan. Perhaps voters reading the pamphlet did not see past the promises of "full employment." I was interested in determining through my analysis if the major newspaper in the state also treated the measure as a "full employment" plan and did not attend to its consequences for the poor and the middle class who would lose valuable social services.

\section{SAMPLING STRATEGY}

In order to get a sample of stories about poverty dispersed across the 1969 and 1990 calendar years I selected dates using a table of random numbers. I searched each daily edition selected from cover to cover and included all types of stories, with the exception of advertisements and letters to 
the editor, as I wanted to examine stories on business and entertainment, editorials, and so on, not just "hard" news stories. I included only stories and editorials which dealt with poverty as problematic in some way.

I continued to search randomly-selected editions until I found 60 stories from each year. Some stories were part of a series of stories covering poverty issues in-depth and spanning several editions. I analyzed these major stories separately from the primary sample, and will discuss them in a separate section.

In 1969 there were two major news dailies in Portland, Oregon; The Oregonian and the oregon Daily Journal. The oregonian, the morning paper, covered mostly non-local news whereas the Journal, the evening paper, covered local stories. I sampled both papers as the Republican Party-affiliated oregonian was believed to be fairiy conservative by many Oregonians, and the Democratic Party-affiliated Journal was believed to be more liberal. In 1981 the oregonian and the Journal merged, resulting in a new oregonian published both the morning and evening.

\section{CONCEPTUAL FRAMES}

A conceptual frame is a set of related ideas which help people to make sense of the world around them (Gamson and Lasch, 1983). Gitlin defines frames as "principles of selection, emphasis and presentation composed of...tacit 
theories about what exists, what happens, and what matters" (Gitlin, 1980: 6). Conceptual frames guide newswriters and editors in deciding what to omit from a story, what to include, and how to present what is included. At the center of conceptual frames are cultural themes, or general ideas about what is good, right and desirable (Gamson and Lasch, 1983) .

I analyze the stories in my sample by looking for challenges presented to the dominant conceptual frame of each historical era. The dominant frame in an historical era is that which is most compatible with the interests of the dominant class at the time. I am assuming that the conceptual frames promoted by elected politicians more often than not represent the interests of the dominant class in this society. Elected officials are usually members of the capitalist class, or are at least dependent on it for economic resources. As these officials have an interest in the maintenance of dominant class hegemony, their conceptualization of poverty and solutions for it will be compatible with the interests of the capitalist class. For this reason I look to the policies of elected officials when defining the dominant frames.

Producers of news stories such as newswriters and editors are also influenced by hegemony. The hegemony of the dominant class in this society helps define reality for the producers of news, and guides their principles of selection. News producers are also dependent on the dominant class for 
sponsorship as they rely on advertisers to provide income, and they may depend on a friendly relationship with powerful individuals who provide inside information (Katz and szecsko, 1981). For all of these reasons news producers have an interest in maintaining hegemony. The news stories they produce will more often than not reflect this interest by actively supporting or at least, rot challenging the dominant frame.

I begin my analysis by identifying the two dominant frames by answering several questions about poverty in the way that I believe the elected officials of each time period might answer those questions. I sought these answers in a number of scholarly accounts of the political and economic policies of both the War on Poverty and the Reagan presidency (Boaz, 1988; Haveman, 1977; Palmer and Sawhill, 1982 and 1984; Piven and Cloward, 1971 and 1982; Zarefsky, 1986).

\section{The War on Poverty frame}

This is the dominant frame for the calendar year 1969. This frame can best be described by answering several questions about poverty from the perspective of the frame and the elected officials who promote it.

Who are the poor? The poor are primarily a minority underclass, usually Black or Hispanic people.

Why are these people poor? They have a deviant culture, developed as a response to the conditions of poverty, which is transmitted generationally. The poor do not have the same 
goals and values as the non-poor; they cannot delay gratification or plan for the future, and they are alienated and marginal. Because the poor cannot act like the non-poor, they do not participate in most social institutions, with the exception of the criminal justice and welfare systems.

What should be done to help these people? Government sponsored programs headed by socially legitimated experts should be implemented, to teach the poor how to be more like the non-poor. When the poor are resocialized into the dominant culture, they will be able to participate in all areas of social life and to pull themselves out of poverty. What are some examples of appropriate programs? Model Cities, Head Start, Job Corps, Community Action, and other programs are designed to teach the poor the culture of the non-poor and to help them participate fully in social life.

What is the moral appeal inherent in this frame? The moral appeal is one of citizen participation, that there is moral value in full participation in all areas of social life. Also implied are ideas of civic duty, that it is the citizen's responsibility to participate appropriately in all social institutions.

Which of Kerbo's four perspectives on poverty are compatible with this frame? The cultural deprivation perspective is most compatible, but the individual responsibility perspective is present in the frame. This 
frame is dominant in part because it is polysemic: it can be interpreted in different ways. Zarefsky (1986: 41) notes that roughly half of those polled by Gallup in 1964 believed that poverty was due to the qualities of individuals and half did not.

By stressing individual deficits as the explanation of poverty, the (War on Poverty) program's designers could appeal to those who believed that poverty primarily was a matter of personal indolence. By stressing cultural, rather than personal, explanations for those deficits, they also could appeal to those who believed that the poor were not to blame for their plight. (Zarefsky, 1986: 41-42)

This division in public opinion in part explains why the culture of poverty perspective appealed to elected officials.

\section{The Reagan-era frame}

The Reagan-era frame is based on the conceptualization of poverty and apropriate solutions for it promoted by the elected officials of the Reagan administration.

Who are the poor? The poor can be those who are working but not making ends meet or are temporarily unemployed (the "working poor") as well as those who have neither a job nor a home (the "homeless"). The poor can be white or non-white. Why are these people poor? The working poor are poor due to various economic conditions, such as high unemployment, seasonal layoffs, economic recession, and so on. The poor can be homeless due to these economic factors, but can also be homeless due to their individual characteristics, like drug and alcohol abuse or mental illness. Although it is 
acknowledged that substance abuse may be a response to economic stresses, the individual must overcome drug and alcohol problems before he or she can get out of poverty.

What can be done to help these people? The working poor can be helped by indirect measures, namely by stimulating economic growth on the corporate level. When corporations are given incentives to expand operations (such as tax breaks and decreased regulation), they will do so and provide more jobs for the unemployed and underemployed. Social service and welfare programs should be administered at the local level, with every effort to require recipients to find employment. The homeless and the working poor in especially dire circumstances should be aided by charitable efforts of private citizens and the non-profit sector.

What are some examples of appropriate antipoverty programs? Job training and placement programs in which all welfare recipients are required to participate will help get these people off the welfare rolls. Charitable organizations such as homeless shelters can provide emergency assistance to those in especially difficult circumstances, and should focus on treating substance abuse and other personal problems which keep the poor individual from functioning properly in society.

What is the moral appeal inherent in this frame? This frame stresses the value of hard work and the importance of individual self-sufficiency. Also important is the value of 
charity and voluntarism; it is morally right for individual citizens to help those less fortunate directly and personally, and this is preferable to government-sponsored antipoverty efforts.

Which of Kerbo's four perspectives on poverty are compatible with this frame? The situational factors perspective is most compatible as there is a heavy emphasis on economic situations as the cause of poverty, yet the individual responsibility perspective also comes into play. This is seen in the importance placed on hard work and independence, and on charity only for the deserving. Like the War on Poverty frame, the Reagan Era frame is polysemic: it appeals to those who believe that poverty is caused by the individual's characteristics, yet allows that those characteristics may be the result of factors external to the individual.

\section{Cultural themes}

I also looked for the presence of cultural themes in the news stories. A cultural theme is a set of general ideas about what is moral, right and good in social life (Gamson and Lasch 1983). Cultural themes are invoked in discussions of poverty but are also present in discussions of other social issues. I anticipated finding two specific cultural themes in the stories from both eras on the basis of my preliminary historical readings. I call them the "humanity first" theme and the "volutarism/charity" theme. 
The "humanity first" theme holds that individuals are entitled to have basic needs met and to be treated with common courtesy and dignity, and that this entitlement is more important than political agendas or economic imperatives. Because these basic needs are so important, it is the government's responsibility to insure that they are met. This theme is consistent with the war on Poverty frame. The "voluntarism/charity" theme stresses the value of individuals helping the truly deserving who cannot help themselves, and is consistent with the Reagan-era frame. Voluntarism is viewed as important as it makes charitable citizens feel good, and allegedly strengthens social bonds and community spirit. This theme includes strong emotional appeals and appears frequently during the holiday season. It is often found in heartwarming or pitiful narratives in human interest stories.

\section{Challenges to the dominant frames}

As I searched for the presence or absence of challenges to the dominant frames I attended to both implicit and explicit messages. I analyzed the how messages were presented and what was left out of the news stories as well as what was included, as I believe omission is often as revealing as inclusion. I did not attempt to quantify specific words or phrases, because I believe as do Todd Gitlin and stuart Hall (Gitlin, 1980) that the frequency with which a word or phrase appears is not the best indicator of its significance, and that messages can be most powerful due to their place in an historical context. 
As an alternative to quantifying messages, I determined whether the stories in the sample presented challenges to the dominant frame. Stories which are consistent with the dominant frame may accept or actively support it. Stories I classified as accepting the dominant frame present information about antipoverty strategies promoted by elected officials without criticism. When a story does not criticize the dominant frame conception of poverty, it tacitly implies that this conception is correct. Such stories will not point out inadequacies in these strategies and programs or question the reasoning behind them, but will also not overtly promote the frame. A story which supports the frame overtly promotes it, stating or implying that the causes of or solutions for poverty proposed by elected officials are proper and desirable.

Because the structural causes perspective critiques the relations of capitalism, to present this perspective is a challenge to capitalist hegemony. Viewpoints and information consistent with the structural causes perspective do appear in news stories, although the perspective itself generally does not. A news source quoted will probably not be quoted extensively enough to present a complete analysis of the relationship between capitalism and poverty, but may be quoted expressing a viewpoint consistent with part of the structural causes perspective. For example, a citizen may be quoted as saying that banking practices in granting real estate loans 
contribute to slum conditions in cities, and that banks must be regulated to insure that loans will be granted to lowincome homeowners. The reader can only know the citizen's opinion on banking and slums, not her opinion on capitalism and poverty in general. It is, of course, quite possible to have regulated banks in a society which does not regulate the economy in any other way. Although the citizen is not quoted as calling for nationalized banks, her views are compatible with the structural causes perspective because she cites some capitalist practices as the cause of a poverty-related problem.

I began my research expecting that challenges to the dominant frame will only appear in news stories in a co-opted form. Co-optation neutralizes challenging views, or absorbs them, assimilating them into the dominant frame. A newswriter can co-opt a challenge in a variety of ways. The writer can quote other sources which contradict the challenging source, or quote only the parts of a structural argument which could also be interpreted as consistent with the dominant frame. The writer can quote several points in a source's argument and then offer a co-opting conclusion of her or his own. She or he can use words like "claimed" and "alleged" unnecessarily and make the source appear less credible. Editors can also neutralize a challenge by choosing a headline or accompanying photo which supports the dominant frame. Co-optation allows the journalist to present several sides to an issue while 
still keeping the story as a whole consistent with the dominant frame.

Challenges to the dominant frame which are not co-opted may appear in mainstream news stories as well, but I anticipated before my analysis that all viewpoints consistent with the structural perspective will be co-opted in one way or another. To allow a challenge to appear without co-optation would be more of a challenge to capitalist class hegemony than I expected the mainstream press would allow. 


\section{ANALYSIS AND FINDINGS}

I began my analysis anticipating several findings. I expected that more stories would be consistent with the dominant frame than would challenge it, illustrating the effect of capitalist hegemony on news texts. I also expected that stories would attend most often to social realities which are included in the dominant frames' conceptualization of poverty. Thus, I anticipated that race and "the ghetto" would be more frequently mentioned in connection with poverty in 1969 than in 1990, and that the homeless would be more often discussed in 1990 than 1969. I expected that race and ethnicity would be de-emphasized in 1990 in relation to poverty. I anticipated that government-sponsored antipoverty programs would be emphasized in 1969, whereas stories in 1990 would emphasize non-profit sector and charitable programs. I also expected that stories on poverty in 1990 would present the "voluntarism/charity" cultural theme more often than those in 1969, and that the "humanity first" would appear most often in 1969.

The language used by newswriters and the sources they quote when discussing poverty in news stories further illustrates how hegemony shapes news texts. I anticipated 
that reporters and sources who support the dominant frames will adopt specific rhetoric which validates these conceptualizations of poverty. I made note of exemplary language, both challenging and consistent with the dominant frames, which appears in the stories. I anticipated that language exemplifying the cultural deprivation perspective would appear in 1969, and that language exemplifying the situational factors perspective would appear in 1990. I also expected that individual responsibility perspective language would appear in both samples, but that few examples of the language of the structural causes perspective would appear in either sample.

Several stories in the sample were part of a series of major stories devoted to covering an issue in-depth, spanning several daily editions. I expected that these major stories would present a more detailed picture of the issues they discuss and would be likely to include news sources with conflicting views. I also expected, however, that the series would not present challenges to the dominant frame without cooptation. A newswriter who presents challenging views and then co-opts them can appear to be "showing both sides" of the issue, while still presenting a story which as a whole validates the dominant frame.

When discussing the findings of my research, I will sometimes refer to specific stories in the sample by number. A numbered list of stories by headline appears in Appendix A. 
Lists of the specific stories referred to by the tables in this chapter can be found in Appendix B.

\section{RELATIONSHIP OF THE STORIES TO THE DOMINANT FRAMES}

In the sample I found many stories which accept or actively support the dominant frame, several which present coopted challenges and a few which present challenges which are not co-opted (see Table I). This confirms my expectation that, following Gramsci, most stories would be consistent with the dominant frames, but runs counter to my anticipation that all challenges would appear in the stories in a co-opted form. In the following, I describe each story type and give an illustration with a detailed discussion of one story.

\section{Stories which support the frames}

A story which supports a dominant frame not only discusses causes of and solutions for poverty proposed by the frame without criticism, it states or implies that such causes and solutions are desirable, appropriate, or correct.

The 1969 oregonian story titled "Medics Find Children Ravaged By Parasites" is an example of a story which supports the war on Poverty frame. The story focuses on a study of poor Black children in the rural south by academic public health experts. The research project includes only Black children, which is consistent with the war on Poverty conception of poverty as a minority problem. They find that the children are infested with intestinal parasites, as are 
TABLE I

RELATIONSHIP OF STORIES TO THE DOMINANT FRAMES*

Relationship to frame

Paper Support Accept $\begin{gathered}\text { Challenge, Challenge, } \\ \text { co-opted not co-opted }\end{gathered}$

oregonian,

$1969(\mathrm{~N}=30)$

14

11

4

1

Journal,

$\underline{1969}(\mathrm{~N}=30)$

10

13

2

$3 * *$

oregonian,

$1990(\mathrm{~N}=60)$

29

14

11

6

TOTAL:

53

38

16

11

$(\mathrm{N}=120)$

(* For detailed figures listing all stories referred to in this and other tables, see Appendix B.)

(** Two stories from the 1969 Journal present challenges to the dominant frame, but it is not apparent if the challenges are consistent with the structural causes perspective.)

the yards of their homes, and that the children eat a substandard diet. Instead of attributing these findings to the failing Southern agricultural economy or to deficient public health programs, the researchers conclude that the childrens' mothers were "uninformed" about how parasites are contracted and that "a lack of information and motivation were among the greatest deficiencies" affecting the health of the children. The researchers state that "until this population can be taught the nature of this disease it cannot be 
eradicated;" they plan to eliminate the parasite epidemic by teaching mothers about nutrition and food preparation. This story supports the frame by depicting an issue of public health as a problem of motivation and education of the poor rather than an issue of economy or of class position. The story does not suggest that the reason why the mothers do not know about parasite transmission, nutrition, or food preparation is because the public education they themselves have access to is deficient.

The 1990 oregonian story titled "New England boom ends with economic bust" is an example of a story which supports the Reagan-era frame. This story discusses economic hardship in New England among the unemployed and the underemployed, attributing this hardship to vague economic forces rather than capitalist economic policy. The story discusses employment rates and "the recession" but does not discuss possible policies adopted by federal and local officials which may have contributed to unemployment. The author states that the recession, and hence, "excessive retail space has collapsed the real estate market in New Hampshire" and notes that developers have built more homes than the demand would support. He does not discuss how corporate policies such as deindustrialization and capital flight contribute to low demand. He states that "real estate problems, in turn, have helped create a banking crisis" and quotes a bank executive as saying that problems with loan repayment and foreclosures have 
been "dragging down banks." Neither the author nor the bank executive addresses the role of banking policies and other corporate policies in the economic downturn. They do not suggest regulation of banking practices or federal aid to borrowers as possible solutions. The solution to the economic woes of the New England states, the story implies, is to aid banks and industries without taking measures to halt deindustrialization.

The newswriter discusses individual unemployed people and attributes their job loss to a vague "economic slowdown." He tells of an unemployed man, who had formerly earned a generous professional salary, going to the Salvation Army for food for his family. Although the newswriter mentions that the charitable programs in New England are running low on food to give out, he does not suggest that charitable programs in general are inadequate for dealing with economic hardship of such scale. He treats charitable programs as the appropriate source of aid for the unemployed and their families.

\section{Stories which accept the frames}

stories which accept the dominant frames discuss the causes of or solutions for poverty proposed by the frames without criticism, but do not promote these causes or solutions as desirable, appropriate, or correct. The 1969 Journal story titled "HEW To Run Head Start" is an example of a story which accepts the war on Poverty frame. This brief wire service story announces that the Nixon administration has 
decided to move Head start from the department of Economic opportunity (the department which administered antipoverty programs during the Johnson administration) to the Department of Health, Education and Welfare. The newswriter speculates that this is as indicator of Nixon's commitment to improving child development and to reaching as many children as possible, but does not state or imply that poor children are socialized into a deviant culture. The story does not promote Head start as necessary for socializing children from a culture of poverty, or suggest that education for poor children will insure that the children will be able to rise out of poverty as adults. The story also does not, however, attempt to discredit the culture of poverty thesis, or suggest that educational programs like Head start are not adequate for eliminating poverty. By not presenting criticisms of the dominant frame, this story tacitly validates it.

The 1990 oregonian opinion column titled "Vulgarity, street life a reflection of urban reality" is an example of a news piece which accepts the Reagan-era frame. The author discusses censorship of allegedly obscene popular music, and concludes that this music merely reflects the ugliness of urban life. She tells of her own experiences as a city dweller, and of her feelings of hopelessness and disgust when confronted with mentally ill homeless people, drug addicts, and slum conditions. This story is consistent with the frame as the author refers to mentally ill and substance-abusing 
homeless and poor people. This tacitly implies that she views homelessness as a problem of the mentally ill or of alcoholics and drug addicts, and not as a problem that potentially affects all members of the working class in late capitalism. She does not suggest that Regean-era public policies will solve the poverty problem (in fact, she does not discuss poverty policy at all), and so does not actively support the frame.

Stories which present co-opted challenges to the frames

Several news stories in the sample presented challenges to the dominant frame but reinterpret those challenges so that they are consistent with capitalist hegemony. A challenge which is consistent with the structural causes perspective on poverty can be co-opted in a variety of ways. The newswriter can quote a challenging source but also quote other sources who support the dominant frame. She or he can quote several points from an argument which could be interpreted as structural and then offer a conclusion based on those points which is consistent with the dominant frame. He or she can present only those elements from a structural argument which, taken out of context, can also be interpreted as consistent with the dominant frame. She or he can discredit a challenge by using words like "alleged" unnecessarily. A story can also present a challenge consistent with the structural causes perspective and be neutralized by an editor who selects a dominant frame headline or photo to accompany it. 
"Mexican Group Learns CAP Rule" from the 1969 Journal illustrates co-optation of a challenge to the war on Poverty frame. An Hispanic antipoverty worker charges the community Action Program in his community with discrimination, noting that Hispanic people are not employed by or allowed to participate in the program. He says that the program instead directs Hispanic citizens to another program aimed at helping migrant workers. He argues that many Hispanic people in his community are not migrant workers and therefore are not well served by that program. The chair of the board of the program informs him that if he can demonstrate that he represents at least twenty-five families in the area the program will consider his complaint. She states that this is standard procedure, but the Hispanic activist claims, as evidence of anti-Hispanic discrimination in the program, that other participating groups have not been required to follow this procedure. The text presents both sides of the issue, but the headline, "Mexican Group Learns CAP Rule" discredits the Hispanic group's claims. The issue is transformed into a lack of knowledge on the part of the Hispanic citizens, not an issue of discrimination. This co-optation is especially powerful given the aim of Community Action. The program was developed in part to teach the poor how to work with middle class institutions, and this headline is consistent with the notion that poor minority groups lack knowledge of bureaucratic processes and must learn these processes in order 
to pull themselves out of poverty.

The 1990 oregonian story, "Work ethic motivates father of Measure $7, "$ illustrates how a challenge by an academic to the Reagan-era frame can be co-opted. This story discusses the sponsor of the ballot measure, a wealthy oregon businessman. He is portrayed as hard worker who "developed a strong work ethic and a sense of community service;" a friend describes him as a man who wants to "save America," and the author points out that he had donated over $\$ 2,000,000$ to local charities. A business associate who knows the sponsor says that he is firmly committed to creating jobs for the needy. An academic expert, however, argues that the sponsor of Measure 7 is acting in self-interest, as the business he operates is labor-intensive. He could benefit greatly from government-subsidized labor. The sponsor is quoted as saying that self-interest is not a motivating factor for him as Measure 7's programs might not be started in his home county, and that the employers of program participants will incur costs when hiring needed supervisors and buying additional equipment.

This story is consistent with the Reagan-era frame because it accepts the sponsor's emphasis on individualism, and implies that those in welfare programs should work for benefits. That the program proposed by the measure would obviously benefit corporations more than participants is treated as natural and desirable. The story as a whole treats 
the measure's sponsor as a concerned citizen trying to provide employment and reform the welfare system despite the fact that the academic quoted views him as a self-interested profiteer. A challenge is presented, but the overwhelming majority of quotes and text supports measure 7 and the Reagan-era frame. This story, as well as several others in the sample, refers to Measure 7 as the "full employment plan."

Stories which present challenges which are not co-opted

I did not expect before analyzing the content of the news stories that any would present challenges to the dominant frame without co-optation. Several in each year, however, did present such challenges.

The 1969 Journal story titled "Indian Deprivation at 'Biafra Level'" is one of the four stories from 1969 which presents a challenge that is not co-opted. The author notes that many Native Americans live in extreme poverty, but does not attribute this poverty to a deviant Indian culture. He instead argues that Native American poverty is caused by greedy capitalists who cheat them out of land and tribal resources, and charges the Bureau of Indian Affairs (BIA) with protecting corporate interests over Indian interests. The author suggests that is not natural and right that corporations profit at Native American's expense, and states that legal action must be taken to hold the BIA accountable for neglecting Indian needs in favor of corporate profits. The 1990 oregonian story titled "Panel points out how 
poverty building among elderly women" is an example of story which presents challenges to the Reagan-era frame without cooptation. The author of the story as well as an advocate for elderly women note that the capitalist system of retirement depends on women to provide unpaid care for their elderly relatives; corporations do not often provide for care in pension plans, and Medicaid and Social security payments are not sufficient to provide paid care. Social security credits are also not given for domestic work, so caregivers receive little or no social security income upon their own retirement. The story points out that women's social security benefits are often much lower than men's because women frequently take time out from the labor force to raise children. For all of these reasons, elderly women are much more often poor than elderly men. This story recognizes that capitalism depends on the unpaid labor of women, and that the government programs designed to provide for the elderly do not take into account women's unpaid work. This challenge would be stronger, however, if the author or the sources quoted suggested government funding to pay women domestic workers, or that corporations should be required to adopt pension plans which would provide paid care for all retirees. They instead propose changes in the social security payment system which will recognize and give credit for women's domestic labor. 
DIFFERENCES IN EMPHASIS, 1969 VS. 1990

As I had anticipated, stories mentioning race in connection with poverty are more common in 1969 than in 1990 (see Table II). Most of these 1969 stories support or accept the dominant frame, and all co-opted challenges from 1969 were made by people of color. Stories mentioning race also appear in 1990, but often focus on Mexican migrant workers in Oregon rather than on Black people or "the ghetto" (see Appendix B).

TABLE II

MORE STORIES FROM 1969 THAN 1990

MENTION RACE

Relationship to frame

$\begin{array}{lccccc}\text { Year } & \text { Support } & \text { Accept } & \begin{array}{l}\text { Challenge, } \\ \text { co-opted }\end{array} & \begin{array}{l}\text { Challenge, } \\ \text { not } \\ \text { co-opted }\end{array} & \text { TOTAL } \\ \frac{1969}{(N=60)} & 9 & 1 & 6 & 2 & 18 \\ \frac{1990}{(N=60)} & 6 & 2 & 1 & 2 & 11\end{array}$

Stories discussing homelessness often appear in the 1990 oregonian (see Table III). In fact, nearly half of the sixty stories from 1990 discussed homelessness. Several of these stories discussed homelessness as caused by mental illness or substance abuse, and a few stories from this year discussed substance abuse among the poor with homes. No stories from 
TABLE III

STORIES EXCLUSIVELY FROM 1990 MENTION

HOMELESSNESS, SUBSTANCE ABUSE AND

MENTAL ILLNESS*

Relationship to frame

Topic

discussed

Homeless-

ness only

8

4

1

Homeless-

ness and

mental

illness

Homeless-

ness and

substance

abuse

Substance

abuse

only

4

Challenge,

Challenge

Support Accept co-opted

not

co-opted TOTAL

(n)

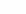

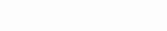

- 2


charitable agency as in many 1990 stories on homelessness.

I anticipated that stories from 1969 would discuss government-sponsored antipoverty programs more often than would stories from 1990. This proved to be true; almost twice as many stories from 1969 focused on government-run programs (see Table IV). About three-fourths of the 1969 stories discussed such programs, as compared to slightly less than half of the 1990 stories.

I expected that stories from 1990 would emphasize charitable and non-profit sector antipoverty programs more often than stories from 1969 and this did bear out in the analysis (see Table IV). over three times as many stories from 1990 discussed such programs, but I did not expect to find that only about one-fourth of the 1990 stories emphasized charities and non-profit organizations. Stories from 1990 which emphasize government-sponsored programs are much more common than stories discussing charities and nonprofits. The great majority of the stories from 1990 that discuss charitable and non-profit programs support the dominant frame.

I expected that the "humanity first" cultural theme would appear in 1969 much more often than in 1990 which did not prove to be the case (see Table VI). The theme appears almost equally often in the two years. Most stories from 1969 which present this theme discuss restricting space program funding until poverty is dealt with; most from 1990 discuss 
TABLE IV

MORE STORIES FROM 1969 THAN 1990

DISCUSSED GOVERNMENT-SPONSORED ANTIPOVERTY PROGRAMS

Relationship to frame

\begin{tabular}{|c|c|c|c|c|c|}
\hline Year & support & Accept & $\begin{array}{l}\text { Challenge, } \\
\text { co-opted }\end{array}$ & $\begin{array}{l}\text { Challenge, } \\
\text { not } \\
\text { co-opted }\end{array}$ & TOTAL \\
\hline$\frac{1969}{(\mathrm{~N}=60)}$ & 18 & 18 & 5 & 3 & 46 \\
\hline$\frac{1990}{(\mathrm{~N}=60)}$ & 7 & 5 & 7 & 6 & 25 \\
\hline
\end{tabular}

TABLE V

MORE STORIES FROM 1990 THAN 1969

DISCUSS CHARITABLE OR NON-PROFIT SECTOR

ANTIPOVERTY PROGRAMS

Relationship to frame

$\begin{array}{lccccc}\text { Year } & \text { Support } & \text { Accept } & \begin{array}{l}\text { Challenge, } \\ \text { co-opted }\end{array} & \begin{array}{l}\text { Challenge, } \\ \text { not } \\ \text { co-opted }\end{array} & \text { TOTAL } \\ \frac{1969}{(\mathrm{~N}=60)} & 2 & 2 & - & - & 4 \\ \frac{1990}{(\mathrm{~N}=60)} & 13 & 1 & 1 & - & 15 \\ \end{array}$


TABLE VI

STORIES FROM 1969 AND 1990

PRESENT THE "HUMANITY FIRST" THEME

ALMOST EQUALLY OFTEN

Relationship to frame

\begin{tabular}{|c|c|c|c|c|c|}
\hline Year & Support & Accept & $\begin{array}{l}\text { Challenge, } \\
\text { co-opted }\end{array}$ & $\begin{array}{l}\text { Challenge, } \\
\text { not } \\
\text { co-opted }\end{array}$ & TOTAL \\
\hline$\frac{1969}{(\mathrm{~N}=60)}$ & 1 & 2 & - & 2 & 5 \\
\hline$\frac{1990}{(\mathrm{~N}=60)}$ & - & 2 & 2 & - & 4 \\
\hline
\end{tabular}

the problems of the homeless. The opinion column titled "Nixon May Give Welfare Priority Over Mars Trip" illustrates the theme well. The columnist supports limiting space program funding and increasing public assistance for the poor. He says that he finds it ironic that Americans seem more surprised that the government would initiate a progressive welfare program than they are that the government would consider spending billions of dollars on space exploration. I anticipated that the "voluntarism/charity" cultural theme would appear most often in 1990, and this proved to be true (see Table VII). The theme appears in only four stories from 1969 (almost as often as the "humanity first" theme), and in fifteen stories from 1990. Most of the 1990 stories support the Reagan-era frame.

The 1990 oregonian story titled "The oregonian Christmas 
TABLE VII

MORE STORIES FROM 1990 THAN 1969

PRESENT THE VOLUNTARISM/CHARITY THEME

Relationship to frame

\begin{tabular}{lccccc} 
Year & Support & Accept & $\begin{array}{l}\text { Challenge, } \\
\text { co-opted }\end{array}$ & $\begin{array}{l}\text { Challenge, } \\
\text { not } \\
\text { co-opted }\end{array}$ & TOTAL \\
\cline { 2 - 4 }$(\mathrm{N}=60)$ & 2 & 2 & - & - & 4 \\
$\frac{1990}{(\mathrm{~N}=60)}$ & 13 & 1 & 1 & - & 15 \\
\hline
\end{tabular}

Stocking Fund: Laotian family struggles" is an example of the theme. The story tells of a hard-working Laotian-American widow whose job does not pay enough for her to support her children. The narrative includes several strong emotional appeals. The author describes how the children do not have winter clothes and cannot play outside when it is cold; the children also have no toys and need school supplies. The author tells that this woman is fulfilling her husband's dying wish by keeping her children in school, but she cannot make ends meet on her paycheck. Readers are encouraged to contribute to The oregonian Christmas stocking Fund so that she and others in need can receive some help.

\section{EXEMPLARY LANGUAGE}

The rhetoric adopted by newswriters and the sources they 
quote illustrates the influence of capitalist hegemony on the content of news texts. I anticipated that language exemplifying the culture of poverty perspective would appear in the 1969 stories, and that language exemplifying the situational factors perspective would appear in 1990. This proved to be the case for both years. I also expected to find individual responsibility language in both years, as this perspective is consistent with both dominant frames in both eras.

When discussing exemplary language I refer to stories in the sample by number. A list of the headlines to which these numbers refer can be found in Appendix A.

\section{Language in the 1969 newspapers}

I have found many examples of "culture of poverty" ideas expressed in both The oregonian and The oregon Daily Journal. Cultural deprivation rhetoric is invoked by only one poor person (in Journal story 8). All others who express these ideas are of the "intelligentsia," or producers of "legitimate" knowledge: for example; journalists, acedemics, government professionals, or elected officials.

Many stories from the 1969 oregonian contain language describing poor people which is consistent with the culture of poverty thesis. The poor are described as "poverty stricken squatters in slums" (Oregonian 10), "social and economic underdogs" (12), and "unskilled Negroes" (13).

Antipoverty programs which are based on a cultural 
deprivation perspective are also described in language which supports the culture of poverty thesis. Resocialization programs are depicted as necessary to "help the poor help themselves" (12). An elected official (14) argues that the Work Incentive program in Oregon helps the poor "build confidence," and an educator (23) says that it is important to get "troubled kids involved with their own destinies." The author of story 27 asserts that Nixon's FAP "strengthens family bonds" and "promotes work" as it "subsidizes poor fathers" and decreases the number of singleparent families caused by "divorce, desertion, or illegitimacy." The policies in place prior to the FAP are said to "reward the father who deserts his family, and penalize the father who sticks with his family and works." This language exemplifies the culture of poverty notion that the poor are tolerant of deviant family structures.

There are also many depictions of poor people which exemplify the cultural deprivation perspective in the Journal. The author of editorial 16 argues that the "poor and ignorant" reproduce faster than the non-poor, and that cities face problems as the poor move from "rural slums to urban ones." The author of story 22 discusses such non-productive persons as "chronic unemployables, sociopaths, welfare recipients, and other public charges" as a group, and argues that resocialization is necessary to "make people producers instead of consumers." 
Antipoverty programs are also described in ways consistent with the culture of poverty thesis. A high-level government employee (25) states that social workers help break the cycle of poverty by preparing the poor for "useful and productive roles in society." A job training program participant discusses his desire to "make something more" of himself (8).

There are several examples of individual responsibility perspective language from 1969 as well. One academic expert (Oregonian 30) likens improving the health care system for low-income families to "forming our soup line at the Hilton." The author of Journal 22 asserts that the "hard core unemployed" "lack motivation." All others expressing such sentiments are working class or poor citizens who are not marginalized: those who are close to, but not living in, poverty. Mexican farm women who are in supervisory positions in oregonian 2 refer to "lazy people on welfare" and discuss the importance of learning "the value of a dollar." A Mexican-American trucker in the same story says that the farm workers should "fight for rights as individuals, not as a group." Working class citizens quoted in oregonian 29 refer to "people who refuse to do a day's work" and argue that "jobs are available, let them work" instead of receiving government food assistance. One citizen in this story states that he is normally against welfare, but that he sees the need to help the "truly desperate." 
There are few examples of language representing the structural causes perspective. A Black minister in oregonian 1 calls welfare a "band-aid solution" to broad social problems, and accuses the government of co-opting militant activists by buying "riot insurance" in the form of increased welfare benefits. The author of Journal 19 refers to "greedy white traders" who take advantage of Native Americans and the Bureau of Indian Affairs, and charges the federal government with "gross criminal neglect" of Native American needs. He typfies white reservation-area traders as "virtual dictators." He argues that the federal government has stood idly by as "business tycoons and Alaska officials" have "cheated" Alaskan Natives.

Exemplary language in 1990

There are few clear examples of language which typifies the situational factors perspective in the 1990 sample. It seems that few "catchphrases" have developed which sum up this perspective. Perhaps the closest thing to a catchphrase this perspective has is the term "working poor," referring to those who have jobs but still have difficulty making ends meet. This phrase appears in several stories in the newspapers sampled from this time period. A homeless shelter worker says that working people can be "two paychecks away from being homeless" in story 30, and a politician in 19 notes that many people want to work are on welfare because they cannot find jobs. 
There are several examples of language which attributes the cause of poverty to vague economic forces, which is consistent with situational factors perspective. In story 5 an elected official attributes poverty to "sluggish productivity, fiscal insolvency, increasing economic stress on working families," the author also discusses "spreading economic downturn." The author of 34 cites "competition at home and abroad," "depressed real estate" conditions, little available credit, and "the recession" as the cause of increasing poverty in New England.

Several stories address deviant behavior as the result of poverty. The author of story 2 mentions a shelter which offers "life skills and spiritual courses designed to resolve problems" faced by the homeless. A homeless shelter worker also states in 35 that the homeless need shelters which are "clean and uplifting" and do not "perpetuate the cycle of homelessness." This comes perilously close to the individual responsibility and cultural deprivation perspectives, yet differs from them in that neither a deviant culture nor personal moral defects are not cited as the cause of the "problems." These problems supposedly result from economic stresses, according to this story.

There are many examples of individual responsibility perspective language present in the 1990 sample. Measure 7's sponsor argues that all citizens should work for a living, regardless of their situations or abilities. He discusses how 
widows will "feel good about paying their own way" if life insurance were abolished (story 27). He, and several newswriters in the 1990 papers, refer to Measure 7 as the "full employment plan," which this sponsor claims represents the interests of the "ordinary guy" (story 29) who is tired of "spoiled" welfare recipients who are "getting something for nothing." He says, "If we don't contribute, we don't get paid," demonstrating his belief that all citizens should be required to work for a wage.

An elected official from New York city quoted in story 54 says that panhandlers are "laying waste to the New York City transportation system" as he justifies a ban on panhandling. A non-profit professional also justifies cuts to a daycare center (story 50) by calling it a "Cadillac center," too expensive for low-income children. A Black opinion columnist (57) asserts that Black people who pool their resources, work hard and avoid drugs will be financially successful; he tells Black people to "do yourself a favor, get a job."

Some stories quote sources who distinguish between the "deserving" and the "undeserving" homeless. Several homeless shelter workers take great pains to reassure reporters that the residents of their shelters are families, not the "guys downtown sleeping in doorways" (story 42). The Salvation Army, according to a representative cited in story 35 , helps only people "who want to re-establish their lives and get out 
of homelessness." Another non-profit worker notes that most homeless people would not be willing to participate in the 60 day "self-improvement courses" required by his shelter (story 48), implying that many of the homeless are lazy.

There are a few examples of language consistent with the structural causes perspective evident in 1990. An academic quoted in story 10 ask "how can we claim to be a kinder, gentler nation with one quarter of children living in poverty?" The for-profit health care system in the U.S. is called "insane" because "some women get too much" health care and some women get none. The author states that "we must address poverty, racism, and terrible differences in quality of life between the poor and the non-poor" and improving health is an "issue of political will and societal commitment."

Protestors against Measure 7 demand that Oregonians "abolish slavery" and demand "decent jobs, not forced labor" (story 23). An employee of the state government says that Measure 7 is "tantamount to slavery."

Finally, an oregon congressman (story 58) criticizes cuts in human services budgets on the federal level, and calls cuts in human service without simultaneous cuts in defense spending a "wrecking ball to the poor."

The language used by newsproducers and the sources they quote illustrates how news texts are shaped by hegemony and how news texts in turn contribute to worldviews which serve 
the interests of the dominant class. I will now turn to discussion of the major stories found in the sampling process.

\section{MAJOR STORIES}

Several stories in the sample are part of a series of stories spanning several daily editions, covering issues indepth. I analyze these major stories in their entirety.

As I expected, these major stories often present many conflicting viewpoints, and several major stories present challenges to the frame which are only weakly co-opted or not co-opted at all. I did not expect that such strong criticisms of dominant-frame ideas would be allowed in mainstream newspapers.

All of the stories which do not challenge the dominant frame, or which present minimal co-opted challenges are from the 1990 sample. For example, the "Post-Cold War America" series discussed recent changes in national policies as well as in public opinion and concerns. The problems we face, now that attention is no longer being distracted by the cold war, are attributed to vague economic forces such as "fiscal insolvency," "sluggish productivity," and a "weakening infrastructure." The author suggests that Americans feel entitled to receive various undeserved social benefits, and that Americans must learn to work harder for the United states to be able to compete in the international market. The steps we must take to remedy domestic problems include improving 
education so that the uneducated do not end up on welfare, and combatting drugs. The author also asserts that the United states must continue to play the role of international policeman regarding Central America and the Middle East now that the cold war is allegedly over, and that this role is vital in protecting United States economic interests. This story presents no challenge to the Reagan Era frame, as it assumes that capitalist policies are legitimate, and because the focus in terms of solving domestic problems is on changing the qualities of individuals by training them for jobs which may not exist, and on offering aid and incentives to corporations.

The "Northwest Forests" series also does not present a strong challenge to the dominant frame. This story depicts the problems in oregon's timber industry-dependent communities as a quarrel between loggers, who need to keep their jobs, and environmentalists, who want to stop logging in old-growth forests. Class enters the picture only in that the loggers are said to represent the working class and the environmentalists are characterized as middle and upper-middle class professional activists. The role of wood-products corporations is minimized, and the only company owners discussed are the "home-grown" types who own small timber operations. The large corporations such as Weyerhauser and Georgia Pacific are not cited as contributing to economic or environmental crises. A worker and the author mention that 
the logging companies have fostered a dependency among workers by relying on the labor of the uneducated and by encouraging certain qualities such as conformity and subservience, but the author does not expound upon this idea. One logger also mentions that the logging companies have purposefully exaggerated the threat posed by environmentalist efforts in order to scare workers and make them more productive and compliant, but this is not explored further. The series does not suggest that the poor management strategy of the timber companies or decreasing demand for wood products in the recessionary economy may be the cause of the present crisis among timber workers. The story does not imply that the corporations should have anticipated the environmental threat and refrained from building single-industry "company towns." The solutions suggested the newswriter and his sources include lifting restrictions on old-growth logging, or keeping the restrictions and promoting service sector industry, such as tourism, in the area. The story mentions that loggers are being retrained in government job placement programs so that they may find new jobs, but no mention is made of where those jobs are to be found. It is quite likely that the displaced timber workers will wind up in service sector jobs which will not pay a sufficient wage, or provide benefits and job security. These people will still be threatened by poverty. There was a two-story series on Measure 7. This series does not present a challenge to the dominant frame, although 
it does challenge Measure 7 itself. These stories discuss the importance of job training programs and "life skills" classes for welfare mothers, and argue that these women are only temporarily using the welfare system to become independent. Welfare mothers who have graduated from training programs are quoted, all very excited about the wonderful opportunity they have been given to make a better life for themselves but no women who have actually found new, well-paying jobs are cited. The causes of these women's poverty, the story states, include substance abuse, bad relationships, and low self-esteem. These problems are overcome through the training and "life skills" programs offered by the welfare department. Measure 7 is not a good proposal, the articles warn, because it will deny future participants the opportunity to take advantage of welfare training programs and become self-sufficient. According to the newswriter, Measure 7 places individuals in dead-end jobs without the proper training to do anything else. The story does not address the likelihood of these women finding good jobs even after the training program, and as it seems likely that their new jobs will also be in the service sector, they will probably still be in danger of poverty.

The series titled "Up from the streets" is perhaps most affirming of the Reagan Era frame. Its three stories cite substance abuse as the obstacle the homeless must surmount, and focus on homeless individuals who overcame substance-related troubles with the help of non-profit 
agencies and then resumed jobs and normal lives. Two of the former homeless, however, work in the low-paying non-profit sector human services field after treatment (both are single males). The other has a job as a bookkeeper. Her bookkeeper's salary is not sufficient to cover the cost of living for herself and her children, and she is assisted by the charitable efforts of her co-workers. This type of private voluntarism is treated as appropriate and effective for supplementing her low wage and providing what public social services do not.

Both major stories from 1969 present challenges to the War on Poverty frame, but the "Uncle Sam's Helping Hand" series in The Oregon Daily Journal presents the stronger challenge. This series examines the federal grant-in-aid system in place during the 1960's and criticizes it for several reasons. The lack of coordination between programs and the complex rules and regulations make federal grant applications impossible for anyone but a professional "grantsman" to understand. These grantsmen are well versed in the ways to get around laws and obtain the maximum grant. of course, only the powerful are able to employ professional grantsmen, and the powerful are therefore most likely to receive grants. The poor are generally not able to take full advantage of the system. The author shows how federal money goes where those who can exert the most pressure on the system, usually corporations, want it to go. For example, 
grants given to education benefit the corporations, as these companies depend on the university system to develop new technology. The grants allocated for transportation and highway construction also benefit the auto and petroleum industries. The author points out that grants are often given to programs which directly contradict each other: for example, the federal government allocates money for solidwaste management, while at the same time funding research on new disposable products. In the mean time, the individuals who are intended to benefit from federal grants are not getting desperately needed funding. Although the war on Poverty is supposed to be aiding the impoverished, the author comments, the amount of federal dollars given to the state of oregon for antipoverty programs is less than the amount of federal tax dollars extracted from the very poor people these programs are supposed to help.

The "Grapes of wrath $1969 "$ series in The Oregonian also presents challenges to the dominant frame but these challenges are co-opted to an extent by strong individual responsibility sentiments from working class and near-poor citizens. The portrayal of the grape boycott by Cesar Chavez and the United Farm Workers' Organizing Committee (UFWOC) is fairly sympathetic. Overall the series supports Chavez, UFWOC, and agricultural reform. Yet several working class and near-poor citizens, as well as one religious leader, suggest that union members do not want to do an honest day's work. 
They further imply that "outside agitators" including foulmouthed and unwashed hippies are responsible for the unrest in Delano, California, the city in which the union is headquartered. The grape growers are portrayed as hardworking "salt of the earth" types who are independent yet oldfashioned; they do not understand why their community is being singled out when the need for agriculture reform exists nationwide. The growers claim to support agriculture reform but not the kind of sweeping social reform suggested by UFWOC. No mention is made of large-scale agribusiness, and government responsibility for enacting farm labor reform is deemphasized. The author seems to support UFwOC yet does not support the alleged hippies or "insincere" outsiders involved in the struggle, and implies that agricultural reform should come about by working within "the system."

Two series in the 1990 sample present structural criticisms and challenge the dominant frame. The "Blueprint for slum" series examines the problems of Portland's predominantly Black neighborhoods. Although the one story in this series which is part of the primary sample does not explicitely mention race, race is discussed elsewhere in the series. This series argues that the North and Northeast sections of Portland have become more slumlike due to a lack of homeowners, and that there are social structural realities which explain this lack. The author points out that most lending institutions refuse to lend less than $\$ 30,000$ for 
home purchase, as these small loans will not net large interest payments. Most of the homes in the areas in question cost less than this. Because of this minimum loan amount, purchasers are often forced to borrow from mortgage companies who charge high interest, issue loans for more than the market value of the property, and demand rapid repayment. Purchasers frequently cannot meet the demands and face foreclosure. Even though banks are required by law to lend to residents of the areas in which they operate, these banks typically loan money to wealthier investors who then rent the properties. Many of the less expensive properties are purchased with cash by landlords as well. These landlords do not monitor the behavior of their tenants and often leave property vacant until property values increase and the real estate can be resold. Because North and Northeast Portland have the highest proportion on Black residents in the city, Black citizens are most affected by such lending policies. The stories do present the views of bankers who defend their practices, but the series is overall criticizes banks for contributing to the decline of North and Northeast Portland. One source from a consumer advocacy group argues that banks should be regulated much like utilities, as banks receive federal insurance. He believes that banks should not be considered fully private institutions because they depend on federal support.

The two-part series on infant mortality rates in the United states and Costa Rica posits the for-profit health 
care delivery system in the United States as the cause of our high infant mortality rate relative to other industrialized nations. A health care professional points out that in this country some women get the best prenatal care in the world, while many women get none at all. This source asserts that our health care system is in effect racist, as it is women and children of color who are disproportionately denied health care. The author calls for a national health care system like that of Costa Rica. Although costa Rica is not a wealthy country, the infant mortality rate there is low, which the author attributes to the accessible prenatal care for all women the Costa Rican government provides. The author and the expert argue that all recent decreases in United States infant mortality are due to advances in high technology medicine which can prevent the deaths of very sick and premature infants. These technologies are very expensive and available only to the wealthy. The author states that the only way for the United states to lower infant mortality overall is to adopt a socialized health care system similar to that in Costa Rica. This is a challenge to the for-profit health care system, but not necessarily a challenge to capitalism. Nationalized health care will also lower costs to corporations which provide health care benefits to employees; many corporations support nationalized health care. The story does, however, recognize the effect of class on infant mortality in this society. 
Overall, most of these major stories are consistent with their respective dominant frames. I did not, however, expect to find so many challenges consistent with the structural causes perspective presented in some of the major stories, or to find that these challenges would be only weakly co-opted or not co-opted.

This completes the discussion of my findings based on my analysis of the stories in the sample, as well as the major stories found in the sampling process. I discuss my conclusions and offer suggestions for future research in Chapter VI. 


\section{CHAPTER VI}

\section{CONCLUSIONS AND SUGGESTIONS FOR FURTHER RESEARCH}

Do the stories I analyze illustrate how news texts are shaped by, and how newswriters promote capitalist class hegemony? A large proportion of news stories in the sample from both years support or accept the respective dominant frames, and emphasize conceptualizations of poverty which are consistent with these frames. I interpret this as an illustration of how newswriters are influenced by the dominant class and how they contribute to the dissemination and validation of hegemonic worldviews.

The stories change to reflect historical context. The stories reflect the decline in government concern with racism in 1990 relative to 1969 , and also reflect the rise of homelessness during the Reagan era. The stories are, however, consistent with the interests of the dominant class. I argue that the changes in news messages show how the content of hegemony changes to admit and absorb or neutralize new events and possible conflicting definitions of reality.

The ideological language found in the stories further demonstrates how news producers are influenced by capitalist hegemony, and illustrates how these news producers in turn use 
language to promote views which serve the interests of the capitalist class.

All of these findings suggest to me that the news stories in the sample are products of a hegemonic cultural apparatus, and that news producers promote definitions of reality which are consistent with the hegemony of the dominant class. However, there are several stories in the samples which present challenges consistent with the structural causes perspective which are not co-opted: how can this be reconciled with hegemony?

I believe that my initial conceptualization of what constitutes a challenge to hegemony was erroneous. I had thought before doing this research that for a news story to present a structural cause of poverty and to imply that a structural solution is necessary would be a real departure from domination by consent.

Several stories in the sample discuss how parts of the capitalist system cause and perpetuate poverty, but do not suggest that poverty is endemic to capitalism. As a researcher familiar with Marxism I am sensitized to the structural causes perspective on poverty. When reading news stories, I recognize that some messages may be consistent with that perspective. Marxism, however, is not part of the dominant culture in the United states. Capitalist hegemony does not include a conceptualization of poverty as endemic to capitalism; therefore readers who are exposed only to 
hegemonic culture will lack a structural interpretive system. They will most likely interpret messages which may be consistent with the structural causes perspective as consistent with the conceptual frame they have been given by the dominant culture. Cultural messages are polysemic: they may be interpreted differently by individuals with different interpretive schemes.

Challenges to the dominant frames may therefore be coopted by omission in addition to being co-opted actively through the journalistic practices discussed previously in Chapter IV and Chapter V. My research reveals that in order for a story to challenge the dominant frame, it must present the structural causes perspective in its entirety, outlining the assumptions of structural theory on poverty. It is not enough for a news story to identify a part or aspect of the economic system as the cause of poverty. To do so does not necessarily imply that poverty is endemic to capitalism. Such messages may also be interpreted as suggesting that poverty is caused by the present, seemingly aberrant state of this capitalist economy.

Although my initial conceptualization of challenges to the dominant frame was in error, my research did reveal much about the expansive quality of capitalist hegemony. In 1969, the capitalist economy was favorable for the middle class. The middle-class was not threatened by poverty, and therefore found the cultural deprivation perspective a reasonable 
explanation for it. The resocialization programs of the War on Poverty seemed appropriate to more prosperous Americans; their own success indicated that the capitalist economic system was working well, so the problems which cause poverty must lie with the poor themselves. The culture of poverty thesis no longer explains poverty to the middle-class citizens of the present day, however. In 1990, even professionals, who had formerly enjoyed economic security, found themselves threatened by poverty. These people will find it more reasonable to attribute poverty to the economy rather than to deviant cultural arrangements. Hence, newswriters may adjust their strategies by taking into account the experiences of their readers and depicting issues in a way that recognizes those experiences.

The news messages I analyzed changed to present economic explanations for poverty, but did not portray the present state of the economy as inevitable in advanced capitalism. Capitalism in general is still treated as natural and proper. The present state of the economy, not the economic system itself, is identified as the cause of poverty. The solution for poverty presented in the press is to stimulate the economy by aiding the capitalist class.

The stories from 1969 placed emphasis on resocializing the poor so that they may be better suited to the jobs which were available. It seems reasonable that such programs were actually of some benefit to the poor who received job training 
and education. These programs may have given some poor people an advantage by showing them how to maneuver through capitalist bureaucracy; if nothing else, some programs trained poor people for employment in the antipoverty establishment. The solutions for homelessness presented in 1990, in contrast, seem inadequate and inappropriate. The structural-level solutions to poverty from 1990 are designed to aid the mystified and reified economy (in reality, to aid the capitalist class) which will create jobs to be filled by the poor. From the perspective of the Reagan-era frame, all the homeless need is to get "back on their feet:" a short stay at a homeless shelter, some "life skills" classes, or a holiday donation of food will help the homeless person overcome personal problems. Then they will supposedly be able to get jobs created by corporations who have taken advantage of incentives to expand. This proposal does not recognize that charity will not solve the problems of advanced capitalism. The canned food will be eaten, the donated clothing will wear out, the shelters will fill up, and there will still be a severe shortage of jobs which pay a living wage and provide necessary benefits. There will still be too few government-sponsored services available for those who cannot participate in the labor force. By presenting solutions for poverty which do not include a redistribution of wealth, the news stories promote the notion that poverty will be eliminated by helping the rich. 
Scholars of the media have noted that news discourse separates politics from economy, implying that they are two autonomous spheres of social life (Jensen, 1987). Such separation of politics and economy is evident in the stories selected. Even those stories which I classified as presenting challenges without co-optation depict only antipoverty activity which does not threaten capitalist class relations. Social actors are shown as resocialization program supporters or participants in 1969, or working for charities in 1990. Occasionally citizens are shown engaging in reformist politics to change economic policies. Citizens engaged in civil disorder are not portrayed as responding to class-based oppression.

I am guilty of separating politics and economy as well by including only stories which deal directly with poverty in my sample. Many stories appeared in the 1969 papers which discussed civil disorder and other types of political action. The incidents of disorder were treated as racial rather than class conflicts, and the stories did not discuss the ecomonic oppression to which the disorder is in part a response. Hence, I did not include these stories in the sample. This problem could be partially remedied by repeating the analysis and including messages on poverty and economically-motivated political action.

Through the process of doing this research I discovered that some of my methods presented other analytical problems. 
My sampling strategy included all stories on poverty, and poverty is a broad subject. The stories in the samples discussed many poverty-related issues, and did not concentrate exclusively on poverty policy. I often found it difficult to see the relation between some messages on poverty and the dominant frames I identified. My frames are based on Kerbo's four perspectives on poverty, all of which deal specifically with policy-making. This could be alleviated somewhat by narrowing the sampling frame to include only stories on specific poverty issues, or by sampling stories listed by certain keywords (e.g., "welfare programs," "homelessness") in the newspaper indexes.

In addition, my random selection of dates did not allow for a sense of continuity in the messages. Examining stories in chronological order would reveal how the messages change to accomodate specific events and issues and to present them in a manner consistent with the dominant frame.

The conventions of news production affect the content of news texts and affect the readers ability to analyze the news. The information presented in the news may be biased in favor of the capitalist class as a result of these conventions. It is not, then, necessary for news producers to intentionally set out to advance the interests of capitalism.

News producers report on the most current events as they happen to attract readers. News stories focus on the present when reporting events and issues and do not often include past 
or future. It is difficult, then, for the reader to piece a number of news stories on the same or similar issues together into a coherent narrative. Newspapers lack "institutional memory," focusing attention on new events as they arise, and abandoning "yesterday's news." News stories also rarely include analysis of events and issues, presenting instead "objective" information, the information which is empirically verifiable. The reader is made passive by "objectivity" and is forced to rely on the journalist's account of scattered events: the journalist was "on the scene," whereas the reader was not. Finally, journalistic accounts often report on issues and events as national level phenomena, ignoring the local level. Such broad reporting removes real people from the media picture, reducing individuals to categories or stereotypes. The reader may find it difficult to match the journalistic picture with her or his own life. Hence, the reader's ability to analyze issues and events is inhibited by the lack of narrative, analysis, and personal relevance in the news texts on which he or she must rely for information.

Newswriters also must often rely on "legitimate experts" for information which is not available to outsiders. I argue, following Gramsci, that these "experts" will likely present information to reporters which is consistent with the interests of the dominant class, as these individuals are frequently members of that class or at least dependent on it. I did not attempt to research the conventions of news 
production in this thesis, instead confining my investigation to the finished product, the news text itself. An investigation of the news production process would add much to this study, by revealing not just what was presented in the newspapers, but how and why it was presented.

I would like to do a similar content analysis in the future, to see how hegemony continues to expand in response to changes in political economy. If action is not taken in the United states to redistribute wealth, more working-class and middle-class people will find themselves in poverty, while the capitalist class grows wealthier. I believe, as did Marx, that the working class will grow increasingly disatisfied as their economic situation worsens. The shift from individual characteristics to economic situations in explaining poverty in the news stories I examined shows how discontent, and its revolutionary potential, have been managed by capitalist cultural hegemony. As the working class becomes still poorer and larger, this discontent may be more difficult to manage. I do not know how capitalist culture will adjust in the future to thwart potential working class revolt, but I expect that the practices of cultural production will change to absorb or neutralize new definitions of reality which may challenge the precepts of capitalist hegemony. Messages in the mainstream press ten or twenty years from now could provide even more insight into the expansive nature of hegemony. 
SELECTED BIBLIOGRAPHY

Angus, Ian H. 1989. "Media Beyond Representation." In Cultural Politics in Contemporary America, Ian Angus and Sut Jhally, eds. New York: Routledge.

Berger, Arthur Asa. 1982. Media Analysis Techniques. London: Sage.

Berger, John. 1977. Ways of Seeing. London: Penguin Books.

Berry, Colin. 1990. "Channel Images and Mental Models: Perceived Bias on British Television." Media, Culture and Society, 12, 231-245.

Boaz, David, ed. 1988. Assessing the Reagan Years. Washington, D.C.: The Cato Institute.

Boggs, Carl. 1984. The Two Revolutions: Gramsci and the Dilemmas of Western Marxism. Boston: South End Press.

Bottomore, Tom, et al, eds. 1983. A Dictionary of Marxist Thought. Cambridge: Harvard University Press.

Condit, Celeste Michele and J. Ann seltzer. 1985. "The Rhetoric of objectivity in the Newspaper Coverage of a Murder Trial." Critical studies in Mass Communication, $2: 3,197-216$.

Faludi, Susan. 1991. Backlash: The Undeclared War Against American Women. New York: Crown.

Fields, Echo E. "Qualitative Content Analysis of Television News: Systematic Techniques." Qualitative Sociology, $11: 3,183-193$.

Flynn, Kevin and Gary Gerhardt. 1989. The Silent Brotherhood: Inside America's Racist Underground. New York: The Free Press.

Forgacs, David, and Geoffrey Nowell-Smith, eds. 1984 . Antonio Gramsci: Selections from Cultural Writings. Cambridge: Harvard University Press.

Gamson, William A. 1990. Talking About Politics. Unpublished manuscript, Boston College. 
Gamson, William A. and Kathryn Lasch. 1983. "The Political Culture of Social Welfare Policy." In Evaluating the Welfare State, Shimon E. Spiro and Ephraim YuchtmanYaar, eds. New York: Academic Press.

Gamson, William A. and Andre Modigliani. 1989. "Media Discourse and Public opinion on Nuclear Power: A Constructionist Approach." American Journal of Sociology, 95:1, 1-38.

Gitlin, Todd. 1980. The whole world is watching: The Mass Media and the Making and Unmaking of the New Left. Berkeley: University of California Press.

Glasser, Theodore and James S. Ettema. 1989. "Investigative Journalism and the Moral order." Critical studies in Mass Communication, $6: 1,1-20$.

Gorelick, Steven. 1989. "'Join Our War': The Construction of Ideology in a Newspaper Crimefighting Campaign." Crime and Dilinquency, 35:3, 421-436.

Grossberg, Lawrence. 1984. "Strategies of Marxist Cultural Interpretation." Critical studies in Mass communication, $1: 4,392-421$.

Gurevitch, Michael, et al, eds. 1982. Culture, Society, and the Media. London: Methuen and co., Ltd.

Haveman, Robert H. 1977. A Decade of Federal Antipoverty Programs: Achievements, Failures, Lessons. New York, Academic Press.

Henry, Susan. 1984. "Juggling the Frying Pan and the Fire: The Portrayal of Employment and Family Life in Seven Women's Magazines, 1975-1982." The Social Science Journal, 21:4, 88-107.

Herman, Edward S. and Noam Chomsky. 1988. Manufacturing Consent: the Political Economy of the Mass Media. New York: Pantheon.

Jensen, Klaus Bruhn. 1987. "News as Ideology: Economic Statistics and Political Ritual in Television Network News." Journal of Communication, 37:1, 10-25.

Katz, Elihu and Tomas Szecsko, eds. 1981. Mass Media and Social Change. London: Sage.

Kerbo, Harold. 1983. Social stratification and Inequality. New York: McGraw. 
Landsman, Gail. 1987. "Indian Activism and the Press: Coverage of the Conflict at Ganienkeh." Anthropological Quarterly, 6:3, 101-113.

Lee, Barrett A., et al. 1990. "Public Beliefs About the Causes of Homelessness." Social Forces, 69:1, 253-265.

Lewis, Oscar. 1959. Five Families: Mexican Case studies in the culture of Poverty. New York: Basic Books.

Liska, Allen E. and William Baccaglini. 1990. "Feeling Safe By Comparison: Crime in the Newspapers." Social Problems, 37:3, 358-374.

Mouffe, Chantal. 1979. Gramsci and Marxist Theory. London: Routledge and Kegan Paul.

1988. "Hegemony and New Political subjects: Toward a New Concept of Democracy." in Marxism and the Interpretation of culture, Lawrence Grossberg, ed. Chicago: University of Ilinois Press.

Palmer, John L. and Isabel V. Sawhill. 1982. The Reagan Experiment: An Examination of the Economic and Social Policies Under the Reagan Administration. Washington, D.C.: The Urban Institute.

------. 1984. The Reagan Record: An Assessment of America's Changing Domestic Priorities. Cambridge: Ballinger Institute.

Piven, Frances Fox, and Richard A. Cloward. 1971. Regulating the Poor: The Functions of Public Welfare. New York: Vintage.

------. 1982. The New Class War: Reagan's Attack on the Welfare State and its Consequences. New York: Pantheon.

Rainwater, Lee and William Yancey. 1967. The Moynihan Report and the Politics of Controversy. Cambridge: M.I.T. Press.

Real, Michael. 1989. Super Media. Newbury Park, CA: Sage. Riggins, stephen Harold. 1990. "News as Texts and Actions." Semiotica, 3:4, 359-374.

Robinson, Michael J. and Andrew Kohut. 1988. "Believability and the Press." Public opinion Quarterly, 52:2, 174-189. 
Salamon, Lester M. and Michael S. Lund. 1985. The Reagan Presidency and the Governing of America. Washington, D.C.: The Urban Institute Press.

Sassoon, Anne Showstack. 1982. Approaches to Gramsci. London: Writers and Readers Publishing Cooperative Society.

Smith, Dorothy. 1987. The Everyday World as Problematic. Boston: Northeastern University Press.

1990. The Conceptual Practices of Power: A Feminist Sociology of Knowledge. Boston: Northeastern University Press.

Snow, Robert P. 1983. Creating Media Culture. London: Sage.

Stempel, Guido and Bruce H. Westley, eds. 1981. Research Methods in Mass Communication. Englewood Cliffs, NJ: Prentice-Hall.

van den Berg, Harry, and Kees van der Veer. 1988. "Semantic Validity: Testing the Operationalization of Ideological Frames of Reference." Quality and Quantity, 22, 311-330.

Volosinov, V.N. 1973. Marxism and the Philosophy of Lanquage. New York: Seminar Press.

Williams, Raymond. 1977. Marxism and Literature. Oxford: Oxford University Press.

Zarefsky, David. 1986. President Johnson's War on Poverty: Rhetoric and History. University, Alabama: University of Alabama Press.

Zijderveld, Anton. 1979. On Cliches. London: Routledge and Kegan Paul. 
APPENDIX A

NUMBERED LIST OF STORIES IN THE SAMPLE, BY HEADLINE 
The Oregonian, 1969

1: "Veteran Minister Says Negro Feels Sense of Alienation From Large Part of Community". Thursday, June 19, 1969; p.33.

2: Part of major story- "Grapes of wrath 1969: Field Veterans Form Backbone of Union Drive". Monday, April 21, 1969; p.1. By Stan Pederman and Robert Olmos, staff.

3: "Job Corps Center Faces Closure". Monday, April 21, 1969; p.18. By Leverett Richards, staff.

4: "Antipoverty Program Overhaul Advocated". Thursday, March 20, 1969; p.16. Wire service.

5: "Nixon Shifts Two Projects From Antipoverty Agency: OEO Loses Job Corps, Head Start". Thursday, February 20, $1969 ;$ p.1. Wire service.

6: "Medics Find Children Ravaged By Parasites". Thursday, February 20, 1969; p.10. Wire service.

7: Opinion Column- "Nixon May Give Welfare Priority Over Mars Trip", by Charles Bartlett. Tuesday, June 3, 1969; p.14.

8: Opinion Column- "Mayor Lindsay Calls For Mobilization To Fight Urban Woes", by Mayor John Lindsay of New York City. Sunday, January 5, 1969; p.7F.

9: "Poverty Unit Faces New Attack By Nixon". Sunday, January 5, 1969; p.21. By Craig Smith, staff.

10: Opinion Column- "Fateful Question of Priorities Raised By Successful Apollo Moonflight", by Arnold Toynbee. Sunday, January 5,$1969 ;$ p.1F.

11: "Food Program Aimed To Improve Diets of Impoverished Children, Mothers Falls Behind Target". Tuesday, May 6, $1969 ;$ p.7. Wire service.

12: "...'to change things that need to be changed'...CityHall-Fighters organized For Poor". Sunday, January 5, 1969; supplemental section, no page number. Wire service.

13: "Sharp Increase Marks Joblessness of Negroes". Tuesday, May 6, 1969; p.1. Wire service.

14: "Panel Okays Launching Welfare Training Program". Tuesday, May 6, 1969; p.8. 
15: "Assistant Director Denounces Model Cities Planning Board For Blocking Progress". Tuesday, December 16, 1969 ; p. 4 .

16: "Toys Stolen At Church". Tuesday, December 16, 1969; p. 5 .

17: "Nixon Views 'New Federalism' As Reflecting Powers of State, Cities". Wednesday, August 20, 1969; p.6.

18: "Church Calls For Fight Against Urban Problem". Wednesday, August 20, 1969; p.12. Wire service.

19: "Dull Model cities Meeting closes On Wild, Bitter Note". Wednesday, August 20, 1969; p.13. By Andrew Mershon, staff.

20: "Morse Cites Elderly Poor". Wednesday, August 20, 1969; p.6. Wire service.

21: "Unions Urged To Give Help". Tuesday, December 18, 1969; p. 16.

22: "City Faces Decision on zoning Change To Allow High Rise Housing Development". Tuesday, December 18, 1969; p.17.

23: "Watts Teacher-Pupil Involvement Beginning To Pay off In Los Angeles". Wednesday, August 20, 1969; p.7. Anne Sullivan, staff.

24: "Dependent Children Aid Biggest Single Program". Wednesday, August 20, 1969; p.8.

25: "County Poverty Pockets Noted". Friday, December 12, $1969 ;$ p. 8 .

26: "Jobless Rate Takes Spurt". Friday, December 12, 1969; p.38. Wire service.

27: "Nixon Studies New Welfare Concept: Cash Aid To Poor Working Fathers". Sunday, April 20, 1969; p.1. Wire service.

28: "7 Job Corps Centers Told To start Closing". Sunday, April 20, 1969; p.16. Wire service.

29: "The Gallup Poll: Public supports Free Food Plan". Sunday, April 20, 1969; p.18. By George Gallup.

30: "Little Money, Many Patients cloud Treatment of LowIncome Families". Sunday, April 20, 1969; p.20. 
The Oregon Daily Journal, 1969.

1: "House Group OKs Ghetto Housing Cut". Thursday, June 19, 1969; p.1. Wire service.

2: "Welfare Increases Confused". Thursday, June 19, 1969; p. 4 .

3: "Mercy Marathon Set For Biafra Aid Walk". Thursday, June 19, 1969; p.4.

4: "Mexican Group Learns CAP Rule". Thursday, June 19, 1969; p.MW3.

5: "High Court Acts: Welfare Residency Requirements Hit". Monday, April 21, 1969; p.1. Wire service.

6: "Welfare Decision Applauded". Monday, April 21, 1969; p. 5 .

7: "Welfare Job Plan Offered". Monday, Apri; 21, 1969; p.6. By Morton Spence, staff.

8: "Aid Program Helps Girl Learn Vocation". Thursday, March 20, 1969; p.9. By Suzanne Richards, staff.

9: "'Drifter's Home' Planned By Washco Action Program". Thursday, March 20, 1969; p.MW5.

10: Part of major story- "Uncle Sam's Helping Hand: Welfare Poor Second To Education In U.S. Fund Allocation". Monday, April 21, 1969; p.4. By James Long, staff.

11: "HEW To Run Head Start". Thursday, February 20, 1969; p.2. Wire service.

12: "Welfare Cost Shift Plan Gains". Thursday, February 20, 1969, p.1. Wire service.

13: "Recipients of Welfare To Have Voice Here". Thursday, February 20, 1969; p.8.

14: "Negro Hits Union Role In Poverty". Tuesday, June 3, 1969 ; p.1. Wire service.

15: "Portlander Praised For Aid To Jobless". Monday, January 6, 1969; p.2.

16: Editorial- "'Where', Not Just 'How Many"". Monday, January 6,$1969 ;$ p. 8 . 
17: "'Windfall' For Poor: HAP Gains Funds To Update Homes". Tuesday, May 6, 1969 ; p.6.

18: "Search Saves Tots' Christmas". Tuesday, December 10, 1969 ; p.9. Wire service.

19: "Indian Deprivation At 'Biafra Level'". Tuesday, December 10, 1969; p.12. By Jack Anderson.

20: Editorial- "Step Toward Eliminating Hunger". Tuesday, December 10, 1969; p.12.

21: "Solons Told of 'Inequities' In Albina". Thursday, January 23, 1969; p.8. By Morton Spence, staff.

22: "Plight of Portland's Poor: Job Training A Vital Force". Tuesday, January 23, 1969; p.2. By Morton Spence, staff.

23: "House OKs Program To Boost Housing". Thursday, March 20,$1969 ;$ p. 5 .

24: "Review of Welfare's Big Budget Begins". Thursday, March 20, 1969 ; p.5.

25: "More Social Workers Viewed As 'Economy'". Monday, March 20, 1969; p.3. By Morton Spence, staff.

26: "Each Mail Delivery Boosts Fund For Children's Christmas Party". Monday, December 9, 1969; p.6.

27: "Paraplegic Seeking 'Legs'". Thursday, December 19, $1969 ;$ p.3. By Jim McWilliams, staff.

28: "Democratic Revolt stalls Poverty Bill". Thursday, December 19, 1969; p.5. By Jack Anderson.

29: Editorial- "Hungry Finally Get Attention". Monday, March 3, 1969; p.10.

30: "Federal Court Rejects Appeal on Unexpected Welfare Fund." Wednesday, June 25, 1969; p.6. Ken Jumper, staff.

The Oregonian, 1990.

1: "Panel points out how poverty building among elderly women". Tuesday, September 11, 1990; p.A12. Wire service. 
2: "Parkrose homeless shelter wins city permit". Tuesday, September 11, 1990; p.B2. By Barbara Peschiera, correspondent.

3: "Search for shelter site near dead end". Tuesday, September 11, 1990; p. B2. By Barbara Peschiera, correspondent.

4: "Snow-CAP picks up needed donations". Tuesday, september 11, 1990; p.B2. By Watford Reed, staff.

5: Part of major story- "Post Cold War America: Citizens begin to see larger enemy at home than abroad". Tuesday. September 11, 1990; p. A2. By David wood, Newhouse News Service.

6: Part of major story- "Blueprint for a slum: Neighborhood activists blame blight on lenders". Tuesday, September 11, 1990; p.A1. By Dee Lane and Steve Mayes, staff.

7: "Special programs give hope for rebuilding neighborhoods". Tuesday, September 11, 1990; p.A14. By Dee Lane, staff.

8: "Expectant mothers abusing drugs". Friday, October 26, 1990; p.C1. By Patrick O'Neill, staff.

9: "New Southeast Health center is open and busy". Saturday, July 7, 1990; p.D3. By Heidi Dunow, staff.

10: Part of major story- "Money, political will crucial to saving babies". Wednesday, october 10, 1990; p.A2. By Dolores Kong, The Boston Globe.

11: "In Milwaukee, many poor students go private". Sunday, September 23, 1990; p.B2. By Bill Graves, staff.

12: "Oregon Issues, Frohnmayer vs. Roberts: The poor- How much should oregon do to relieve the effects of poverty?". Sunday, September 23, 1990; p.B5. By Donald J. Sterling, Jr.

13: "Regional classic revived". Sunday, September 23, 1990; p.C2. By Paul Pintarich, staff.

14: "Critics fear choice proposal too restrictive for poor". Sunday, September 23, 1990; p.D2. By Bill Graves, staff. 
15: "Nurse spends year training others in Indonesian hospital". Thursday, July 5, 1990; Portland Extra p.2. By Linda Campillo, correspondent.

16: "Education project sets sights on expanded services". Thursday, July 5, 1990; Portland Extra p.2.

17: Editorial- "For mothers and children". Thursday, July 5,$1990 ;$ p.B6.

18: Opinion column- "Home ownership vanishing in Portland", by T.K. Jones. Thursday, July 5, 1990; p.B5.

19: "Job initiative proposes workfare for 6 counties". Thursday, July 5, 1990; p.A11.

20: "San Francisco mayor tells police to roust homeless from camp outside City Hall". Thursday, July 5, 1990; p.A10. wire service.

21: "Pair's hopes, dreams turn into nightmare". Sunday, November 25, 1990; p.A1. Rick Bella, staff.

22: "Indians finally again see bountiful harvests". Sunday, November 25, 1990; pC7. By Robert H. White.

23: "K-Falls bank target of protest". Saturday, October 27, 1990 ; p.D5. By Roy Scarbrough, correspondent.

24: Part of a major story- "A Special Report: A scary new day is dawning". Saturday, October 27, 1990; p.A1. Brian T. Meehan, staff.

25: Opinion column- "Unintended consequences: Civilized no-fault divorce laws leave mothers, children impoverished", by Ellen Goodman. Tuesday, January 2 , $1990 ;$ p.B5.

26: "Grant to boost Head Start plan". Saturday, July 28, 1990 ; p.C8.

27: "Work ethic motivates father of Measure 7". Monday, September 17, 1990; p.B5. By Gordon oliver, staff.

28: "Experimental program opens door to workplace". Monday, September 17, 1990; p.B5. By Gordon Oliver, staff.

29: Part of major story- "Full employment backers face huge mission". Monday, September 17, 1990; p.B1. BY Gordon Oliver, staff. 
30: "Rescue Mission buys 2.3 acres for shelter". Monday, December 18, 1990; p.C2. By Ken Brenner, staff.

31: "Eugene-area charities note decrease in holiday donations". Monday, December 18, 1990; p.C2. By Kathleen Monje, correspondent.

32: "The Oregonian Christmas Stocking Fund: Laotian family struggles". Monday, December 18, 1990; p.D1. Janet Filips, staff.

33: "Volunteers can change holidays from bleak to cheerful". Monday, December 18, 1990; p.D4. BY Sandra Diebel, special writer.

34: "New England boom ends with economic bust". Tuesday, July 3, 1990; p.B1. By George Esper, staff.

35: "Shelter cleanup first priority". Tuesday, July 3, 1990; p.C1. By Gordon Oliver, staff.

36: "River washed away dream of better life". Tuesday, July 3, 1990; p.C2. By Steve Amick, staff.

37: "Housing for women planned". Tuesday, July 3, 1990; p.C2. By Linda Campillo, correspondent.

38: "Relocation funds on tap". Tuesday, July 3, 1990; p.C1.

39: "Food plan gets boost of $\$ 219,000 "$. Tuesday, July 3, 1990; p.C3.

40: Opinion column- "Vulgarity, street life a reflection of urban reality", by Ewa Zadrzynska. Tuesday, July 3, $1990 ;$ p.C5.

41: "Damon Wayans". Saturday, September 15, 1990; p.C2. wire service.

42: "Portland Rescue Mission eyes shelter in Parkrose". Wednesday, June 20, 1990; p.D2. By Barbara Peschiera, correspondent.

43: "Salem group volunteers to distribute food to migrant farm worker camps". Wednesday, June 20, 1990; p.D6. By Cheryl Martinis, correspondent.

44: "Street and Stage: Ensemble's spontaniety, improvisation reveal the 'real deal' of homeless life". Friday, December 7, 1990; p.K24. By Randy Gragg, staff. 
45: Opinion column- "More law and order urged, but few willing to pay for it", by John Painter, Jr, staff. Friday, June 29, 1990; p.C7.

46: Opinion column-"U.S. help for big cities? Not from administration", by Mike Royko. Friday, June 29, 1990; p.C7.

47: "Workers strike Chiquita". Friday, June 29, 1990; p.D15.

48: "Rescue Mission lays out plans for homeless shelter". Friday, June 29, 1990; p.C2. By Barbara Peschiera, correspondent.

49: "Housing authority considers low income project in Gresham". Friday, June 29, 1990; p.C2. By Maya Blackmun, staff.

50: "United way cuts allocations to member agencies". Friday, June 29, 1990; p.C3. By Gordon Oliver, staff.

51: "Grower set to ante up back wages". Friday, June 29, 1990; p.D10. BY Eric Goranson, staff.

52: Editorial- "Rekindle 1,000 points". Friday, June 29, $1990 ;$ p.C6.

53: "Greenhouse program to give homeless kids prom". Friday, June 29, 1990; p.C2. By Linda Campillo, correspondent.

54: "NY subway panhandlers to get boot". Friday, June 1, 1990; p.A20. Wire service.

55: "Shelter opens as another closes". Friday, June 1, 1990; p.D1. By Gordon Oliver, staff.

56: "Homeless families leave Troutdale campsite". Friday, June 1, 1990; p.D2 . By Barbara Peschiera, correspondent.

57: Opinion column- "Many blacks do work hard, start businesses", by Clarence Page. Friday, June 1, 1990; p.D7.

58: "Wyden opposes cuts in social services". Sunday, September 2, 1990; p.C2.

59: "Auction set to provide medical aid". Friday, october 26,$1990 ;$ p.C2. 
60: Part of major story- "Up from the streets". Sunday, September 2, 1990; p.C1. By Jann Mitchell, staff. 
APPENDIX B

LISTS OF SPECIFIC STORIES

REFERRED TO IN TABLES I - VII 
STORIES CONSISTENT WITH THE

WAR ON POVERTY FRAME

1969 NEWSPAPERS

Stories which accept the frame

Oregonian:

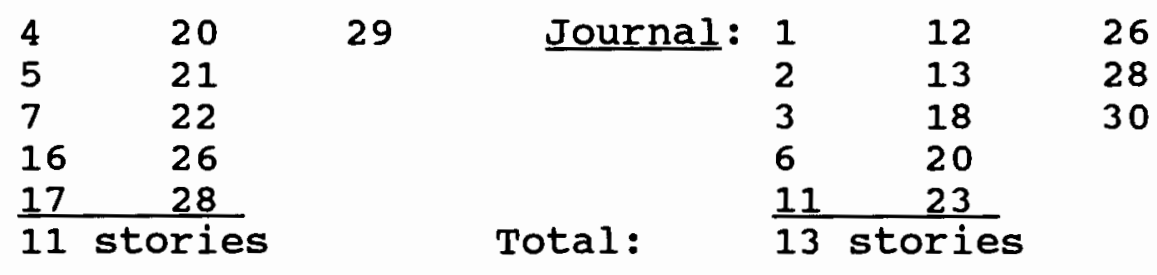

Total not challenging the frame: 24 stories

Stories which support the frame

$\begin{array}{lllllll}\text { Oregonian: } & 3 & 11 & 23 & \text { Journal: } & 5 & 16 \\ & 6 & 12 & 24 & & 7 & 17 \\ & 8 & 13 & 25 & & 8 & 22 \\ & 9 & 14 & 27 & & 9 & 25 \\ & 10 & 18 & & & 15 & 27 \\ \text { Total: } & 14 \text { stories } & & \text { Total: } & 10 \text { stories }\end{array}$

Total supporting the frame: 24 stories

STORIES WHICH PRESENT CHALLENGES TO THE WAR ON POVERTY FRAME, 1969

Co-opted challenges:

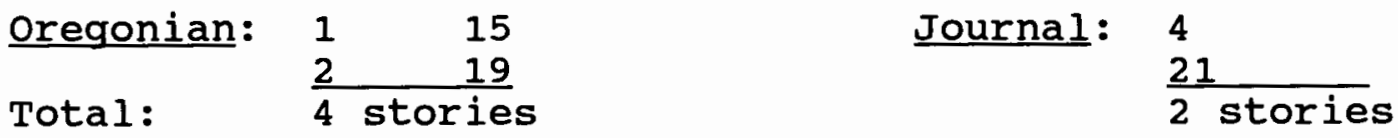

Total presenting challenges which are co-opted: 6 stories

Challenges which are not co-opted:

Oregonian: 30

Journal: $\quad 10 \quad 19$

Total:

1 story

$\frac{14}{3 \text { stories }}$

Total presenting challenges which are not co-opted: 4 stories 


\section{STORIES CONSISTENT WITH THE \\ REAGAN ERA FRAME \\ 1990 SAMPLE}

Stories which accept the frame

$\begin{array}{llll} & 3 & 39 & 49 \\ & 13 & 40 & 51 \\ & 25 & 41 & 55 \\ 34 & 43 & 56 \\ \text { Total: } & 38 & 44 & \end{array}$

Stories which support the frame

$\begin{array}{llllll}2 & 15 & 26 & 33 & 47 & 54 \\ 4 & 16 & 28 & 35 & 48 & 57 \\ 5 & 19 & 30 & 36 & 50 & 59 \\ 8 & 22 & 31 & 37 & 52 & 60 \\ 9 & 24 & 32 & 42 & 53 & \end{array}$

Total: 29 stories

STORIES PRESENTING CHALLENGES

TO THE REAGAN-ERA FRAME, 1990

stories presenting challenges which are co-opted:

\begin{tabular}{ccc}
7 & 20 & 58 \\
11 & 21 & \\
12 & 27 \\
14 & 29 \\
Total: & 18 & 45 \\
\hline & stories
\end{tabular}

stories presenting challenges which are not co-opted:

$\begin{array}{ll}1 & 46 \\ 6 & \\ 10 \\ 17 \\ \text { Total: } & \frac{23}{6 \text { stories }}\end{array}$


STORIES MENTIONING RACE

IN CONNECTION WITH POVERTY

1969

Oregonian

Journal

Black: 1

Hispanic: 2

12

Black: 14

3

12

"Ghetto": 23

8

12

13

15

18

19

Total: 12 stories

Total: 6 stories

Total mentioning race, 1969 papers: 18 stories

STORIES MENTIONING RACE

IN CONNECTION WITH POVERTY

1990

Mexican migrant workers: $4,36,43,51$

Hispanic: 11

Black: $10,11,41,57$

Native American: 22

Southeast Asian immigrants: 32

Race in general: 46

Total mentioning race, 1990 papers: 11 stories 
STORIES FROM 1990

DISCUSSING MENTAL ILLNESS,

SUBSTANCE ABUSE, AND HOMELESSNESS
Mental illness

$\underline{40 \quad 56}$

Total: 2 stories

Substance abuse

$8 \quad 22$

$12 \quad 29$

$13 \quad 37$

$16 \quad 57$

$\underline{20 \quad 60}$

Total: 10 stories
Homelessness, shelters

\begin{tabular}{ll}
2 & 42 \\
3 & 44 \\
$13 * *$ & 48 \\
$16 * *$ & 53 \\
$20 * *$ & 55 \\
30 & $56 *$ \\
33 & $60 * *$ \\
35 & \\
38 & \\
$40 *$ & \\
41 & \\
\hline
\end{tabular}

Total: 18 stories

(* indicates stories mentioning mentally ill homeless people.)

(** indicates stories mentioning homeless people with arug and/or alcohol problems.)

STORIES DISCUSSING

GOVERNMENT-SPONSORED ANTIPOVERTY PROGRAMS

1969

Oregonian, 1969

\begin{tabular}{lll}
1 & 11 & 28 \\
2 & 14 & 29 \\
3 & 15 & 30 \\
4 & 17 & \\
5 & 19 & \\
6 & 20 & \\
7 & 23 & \\
8 & 24 & \\
9 & 25 & \\
10 & 27 \\
\hline
\end{tabular}

Total: 23 stories
Journal, 1969

\begin{tabular}{lll}
1 & 13 & 26 \\
2 & 15 & 29 \\
4 & 17 & 30 \\
5 & 19 & \\
6 & 20 & \\
7 & 21 & \\
8 & 22 & \\
9 & 23 & \\
11 & 24 & \\
12 & 25 \\
\hline
\end{tabular}

Total: 23 stories

Total discussing government-sponsored programs in 1969: 
Oregonian, 1990

\begin{tabular}{lll}
1 & 18 & 39 \\
3 & $19 *$ & 45 \\
4 & 20 & 46 \\
5 & 22 & 49 \\
6 & $23 *$ & 56 \\
9 & 24 & \\
10 & $27 *$ & \\
11 & $29 *$ & \\
12 & 37 & \\
17 & 38 & \\
\hline
\end{tabular}

Total discussing government-sponsored programs in 1990:

25 stories

(* indicates that the government-sponsored programs mentioned were among those proposed by ballot measure 7. )

STORIES DISCUSSING NON-PROFIT SECTOR

AND CHARITABLE ANTIPOVERTY PROGRAMS

1969

oregonian, 1969

Journal, 1969

12

16

3

18

18

26

21

27

Total: 4 stories

Total: 4 stories 
STORIES DISCUSSING CHARITABLE AND

NON-PROFIT SECTOR ANTIPOVERTY PROGRAMS

1990

Oregonian, 1990

\begin{tabular}{lll}
2 & 28 & 48 \\
4 & 30 & 50 \\
5 & 31 & 52 \\
7 & 32 & 53 \\
9 & 33 & 55 \\
10 & 34 & 58 \\
15 & 35 & 60 \\
16 & 36 & \\
21 & 42 & \\
26 & 43 \\
\hline
\end{tabular}

Total: 27 stories

STORIES PRESENTING THE "HUMANITY FIRST"

CULTURAL THEME, 1969 VS. 1990

Oregonian, 1969

$7 *$

$10 *$

30

Total presenting theme in 1969: 5 stories, 3 of which discuss the space program.

(* indicates stories which discuss cutting space program funding before cutting funding to antipoverty programs.)

oregonian, 1990

$13 \quad 21$

$\underline{20 \quad 44}$

Total presenting theme in 1990: 4 stories, all of which discuss the homeless. 
STORIES PRESENTING THE

VOLUNTARISM/CHARITY CULTURAL THEMES

1969 VS. 1990

Oregonian, 1969

18

Total presenting theme in 1969:

Oregonian, 1990

$4 \quad 35$

$9 \quad 36$

$15 \quad 43$

$16 \quad 53$

$21 \quad 59$

26

30

31

32

33

Total presenting theme in 1990: 15 stories
Journal, 1969

18

26

27

4 stories 
APPENDIX C

MAJOR STORIES, LISTED BY HEADLINES 
The Oregonian, 1969.

"Grapes of Wrath 1969"- Stan Pederman and Robert olmos, staff.

"Boycott Seeks Union Rights In Vineyards". Sunday, April 20,$1969 ;$ p.1.

"Field Veterans Form Backbone of Union Drive". Monday, April 21, 1969; p.16.

"Need For Massive Social Reform In Agriculture stressed By Chavez". Tuesday, April 22, 1969; p.14.

"Four-Year Labor Dispute Wracks Delano Spiritually, Mentally". Wednesday, April 23, 1969; p.20.

"Vineyard Owners Proud of Early start In Family Fields". Thursday, April 24, 1969; p.32.

"Young Idealists Form Vanguard of Boycott". Friday, April 25, 1969 ; p.15.

"Chavez And Union Remain Because of National Conscience" . Sunday, April 26, 1969; p.47.

The Oregon Daily Journal, 1969.

"Uncle Sam's Helping Hand"- James Long, staff.

"Federal Aid Big Worry To Solons". Monday, April 14, $1969 ;$ p. 1 .

"\$20 Billion In Aid Gets 'Lost' In Maze". Tuesday, April 15,1969 ; p. 1 .

"Grantsmanship Forms Major Industry". Wednesday, April 16,1969 ; p. 6 .

"Red Tape Lets Grantsman 'Finagle'". Thursday, April 17, $1969 ;$ p. 10 .

"Self-Interest Plays Major Role In Federal Grants". Friday, April 18, 1969; p.3.

"Lack of Local Control Stirs Aid Controversy". Saturday, April 19, 1969 ; p.3.

"Welfare Poor second To Education In U.S. Fund Allocation". Monday, April 21, 1969; p.4. 
"Higher Education Now Working Part of U.S. Industry". Tuesday, April 22, 1969; p.6.

"Most Aid Goes To Where 'Pressure' Puts It". Wednesday, April 23, 1969; p.7.

"Problem Not 'Mismanagement', But 'Rationality'". Thursday, April 24, 1969; p.8.

The Oregonian, 1990.

"Post-Cold War America"- David Wood, Newhouse News Service.

"Array of frightening issues lines up to replace cold war". Sunday, september 9, 1990; p.A2.

"Persian Gulf crisis changes world's strategic realities". Monday, September 10, 1990; p.A2.

"Citizens begin to see larger enemy at home than abroad". Tuesday, september 11, 1990; p.A2.

"Gridlock in Congress blocks action to solve problems". Wednesday, September 12, 1990; p.A2.

"Blueprint for a slum"- Dee Lane and Steve Mayes, staff.

"Consumers and state misled". Sunday, September 9, 1990; p.A1.

"Major lenders aid decline of NE Portland". Monday, september 10, 1990; p.Al.

"Neighborhood activists blame blight on lenders". Tuesday, September 11, 1990; p.A1.

Infant Mortality in the United States vs. Costa RicaDolores Kong, The Boston Globe.

"Money, political will crucial to saving babies". Wednesday, October 10, 1990; p.A2.

"Nation concentrates on health care basics". Thursday, October 11, 1990; p.A2. 
"Northwest Forests"- Brian T. Meehan, staff.

"Lives in transition". Sunday, October 21, 1990; p.A1.

"Factions tearing at the fabric of the forest". Monday, October 22, 1990; p.A1.

"Changing values buffet 'the outfit'". Tuesday, October 23, 1990; p.A1.

"Mill owners struggling to survive". Wednesday, October 24,1990 ; p.A1.

"Workers wonder: 'Will it be me?'". Thursday, October 25, 1990; p.A1.

"A time of passionate convictions". Friday, October 26, $1990 ;$ p.A1.

"A scary new day is dawning". Saturday, October 27, $1990 ;$ p.A1.

Measure 7 series- Gordon Oliver, staff.

"Welfare to workplace: System faces reform in oregon, U.S.". Sunday, September 16, 1990; p.C1.

"Full Employment backer face huge mission". Monday, September 17, 1990; p.B1.

"Up from the streets"- Jann Mitchell, staff.

"Up from the streets: Home was a cardboard box before Harbor Light helped". Sunday, September 2, 1990; p.C1.

"Finally home: A victim of domestic violence struggles to break free and find a new life for herself and her kids". Monday, september 3, 1990; p.F1.

"Crash turns life around: Head-on accident convinces addict to leave streets, change lifestyle". Tuesday, September 4, 1990; p.D1. 